\title{
Inter- and transdisciplinary scenario construction to explore future land-use options in southern Amazonia
}

\author{
$\underline{\text { Regine Schönenberg }}^{1}$, Rüdiger Schaldach $^{2}$, Tobia Lakes $^{3}$, Jan Göpel $^{2}$ and Florian Gollnow ${ }^{3}$
}

\begin{abstract}
Our aim with this paper is to present a novel approach for developing story lines and scenarios by combining qualitative knowledge and quantitative data from different disciplines and discussing the results with relevant decision makers. This research strategy offers a solid foundation for perspectives into the future. The "laboratory" is the Brazilian Amazon, one of the hotspots of land-use change where local and global interests both collide and converge: local livelihoods are affected by regional and global climate change and by the loss of biodiversity caused by local and global economic interests in agro-industrial land use; such use contributes, in turn, to climate change. After decades of diverse policy interventions the question arises: What can we learn from past trajectories for a more sustainable development in the future? To answer this question, we combined qualitative story lines for the region, reviewed by local experts, with quantitative land-use scenarios, to study their regional and local manifestations in space. These results were then discussed again with local and national experts. Our findings suggest that in-depth knowledge of the diverging perspectives at a very local level is a fundamental prerequisite for downscaling global scenarios and upscaling local approaches to sustainable land-use management and thus, to producing communicable and applicable results.
\end{abstract}

Key Words: agriculture; Amazon; Brazil; environmental protection; land-use change; scenarios; story lines; transdisciplinarity

\section{INTRODUCTION}

The region along Highway-163 in the states of Mato Grosso and Pará in the southern part of the Brazilian Amazon is one of the world's deforestation hotspots. Along its $1780 \mathrm{~km}$ route, Highway-163 connects the highly market-oriented soy bean State of Mato Grosso with the State of Pará, where less formalized cattle-ranching still dominates. The history of the highway is paradigmatic for the postindigenous occupation of the Amazon (Santos 1980), which remains caught between abandonment and authoritarian state interventions. When the military government started the construction of highways in the 1970s, two main drivers were behind their policy: opening up an outlet for poor, landless families as well as capitalized farmers in search of more land from the south and northeast, and integrating the areas into the national territory, thereby securing state sovereignty (Becker 1982). In the states of Mato Grosso and Pará, institutional overlapping and a diffuse land-titling process prone to bribery, corruption, and fraud (Foweraker 1981) determined the political culture that persists today. Instead of realizing the idea of an orderly state-controlled colonization, the newly founded towns and nearby forests were overrun by families in search of a new future (Preti 1993), often relying on private colonization initiatives. The overburdened local institutions at the newly opened frontiers failed to provide the minimum public services (Schönenberg 2011) and the political and social disorder led to skyrocketing deforestation rates (Fearnside 2007) that resonated nationally and internationally from 1988 onward. These changes led to high $\mathrm{CO}_{2}$ emissions from soils and vegetation as well as high losses of biodiversity (Coy 2001a,b, Kohlhepp 2002, Lapola et al. 2014). For example, in the 1990s and early 2000s deforestation was one of the largest contributing factors in Brazil's greenhouse gas emissions (Lapola et al. 2014). Since the mid-1990s, various programs, norms, and surveillance technologies were implemented to limit deforestation (Hayes and Rajão 2011). These developments, coupled with the further intensification of agricultural systems and decreasing world market prices for soybeans, led to a significant decrease in the rate of deforestation. Currently, indicators are showing a slightly renewed increase in deforestation and the expansion of agricultural land (Fearnside 2015), a tendency that might pick up when Brazil's Soy Moratorium (Gibbs et al. 2015) will no longer be enforced (Tollefson 2016), the Cattle Agreement expires (Nepstad et al. 2014), and world market prices for soy and cotton rise. For this reason, the analysis of future land-use change trajectories is an essential element when framing policies that aim at reducing land-use related greenhouse gas emissions as an important means of climate mitigation and biodiversity protection.

Because of the inherent complexities of observed and expected land-use change processes, such an analysis requires an inter- and transdisciplinary approach that integrates perspectives from the social sciences, economics, natural sciences, and land-use planning agencies (Jahn et al. 2012, Scholz 2012). In that context, scenario-building has emerged as a well-established method for taking into account mid- to long-term perspectives across spatial scales and across disciplines for a specific region (Kok et al. 2007). Scenarios are plausible descriptions of how the future may unfold that can combine qualitative and quantitative elements (Alcamo 2008, Rounsevell and Metzger 2010). Examples for qualitative elements are story lines, short narratives that describe an image of a future world. In contrast quantitative elements comprise numerical data of future development trends of scenario key drivers, e.g., population growth or economic development. This information is often generated by simulation models. The story and simulation approach (SAS) introduced by Alcamo (2008) combines the advantages of both elements: the potential

${ }^{1}$ Latin America Institute, Free University Berlin, ${ }^{2}$ Center for Environmental Systems Research (CESR), University of Kassel, ${ }^{3}$ Department of Geography, Humboldt Universität Berlin 
complexity and richness of story lines and the clear structure of quantitative data. We follow the climate change-related guidelines of the Intergovernmental Panel on Climate Change, which has introduced an approach to facilitate the process of identifying and describing alternative future developments by combining qualitative and quantitative data (IPCC 2000). In past years different techniques have been developed to bridge the interface between different disciplines and to guarantee participation across groups. Participatory methods have been shown to offer new insights and to provide a wider picture, particularly when scientists, policy makers, and other stakeholders are brought together to develop their vision of the future in a joint approach. However, actors have different views depending on their particular spatial scale, as with the global interest in carbon storage on the part of NGOs versus the local interest in land use for agricultural crop production by farmers living there. Therefore, not only must the process of scenario-building bridge different disciplines, but also spatial scales have to be bridged by transferring scenario results and their implications from the global to the regional level (e.g., Verburg et al. 2006).

The Amazon in particular has been the subject of various studies on land-use change analysis in the past and has gained even more interest in recent years with the discussion of the role of the Brazilian Amazon in the climate change debate (Fearnside 2013). Most of these studies have focused on past changes in land use that were observed either from land-use data based on remote sensing or from statistical or census data (Soares-Filho et al. 2004). The knowledge thus obtained was then used for developing possible future development paths for the respective region (Verburg et al. 2013). However, up to now scenario-building in the Amazon region is often limited to a top-down approach that does not allow for the inclusion of actors with diverging perspectives on land use, nor were the developed scenarios specifically reviewed with local and regional stakeholders (Fearnside et al. 2013). According to Dalla-Nora et al. (2014) most existing efforts neglect the linkage between regional and global drivers or rely on highly idealized representations of regional land-protection strategies without considering existing policy frameworks (e.g., Lapola et al. 2011). Only recently, participatory approaches were applied for scenario-building, for example related to territorial planning in the Lago Grande area in Pará (Folhes et al. 2015) and to forest transition in the whole Amazon region within the AMAZALERT project (Aguiar et al. 2016).

We focus on the scenario construction process within the interand transdisciplinary Carbiocial (German; http://www. carbiocial.de) and CARBIOMA (Brazilian; http://hotsites.cnpaf. embrapa.br/carbioma/index.php) research projects that aim at investigating viable carbon-optimized land management strategies for maintaining ecosystem services under changing climate conditions in southern Amazonia (Gerold et al. 2014). Following the SAS approach our scenarios combine story lines and simulation-based analyses. In contrast to the regional scenario exercise by Aguiar et al. (2016) that concentrates on deforestation, we put a greater emphasis on the development perspectives of the agricultural sector (including intensification) as well as on societal trends such as legal innovations and dietary patterns as main drivers of land-use change in southern Amazonia. In the Carbiocial/Carbioma-context we understand interdisciplinarity as issue-related co-operation and common construction of new knowledge, including the understanding of the methodologies of the others, and the communication in meanings of results; transdisciplinarity we define as co-operation with nonacademic partners and stakeholders, including the acknowledgement of nonacademic knowledge as equally relevant (Jahn et al. 2012). The unifying common starting point of our interdisciplinary research-group was the focus on trajectories of different facets of land-use change. Because future scenarios are governed by past developments, we understand our research area as the dynamic result of historical processes such as naturetransformations, human occupation, and of biographies of individual actors that impact on both legal structures and processes of decision making. Within the Carbiocial project the scenario construction process developed a proper dynamic and influenced both knowledge production and scientific communication. In this article we describe, analyze, and contextualize our modus operandi and demonstrate the advantage of the interdisciplinarity of our research group, which included the fields of geo-ecology, environmental technology, physical geography, and political science. Also, we describe how our story lines were translated into quantitative data regarding the future development of main drivers of land-use change, and illustrate how land-use models were applied to generate spatially explicit information on the resulting land-use change. Finally, we discuss the repercussions of scenario construction for knowledge production in the Carbiocial project. More specifically, we aim to shed light on the following research questions: (1) Can locally adapted story lines be developed for southern Amazonia by learning from different disciplines? (2) How can qualitative knowledge and quantitative spatial modeling be combined to produce scenario maps of future land-use development?

\section{PATTERNS OF HUMAN OCCUPATION}

The guiding principle of the nonindigenous occupation of the Amazon basin since the 16th century was to conquer territory, resources, and manpower. It was during that early period that the basis for the current land-tenureship structure was laid out by the creation of capitanias, vast land donations and political units where the often military governors began to call for new settlers to consolidate their land claims. The majority of the people who heeded such calls came as adventurers on expeditions to capture indigenous slaves while looking for precious metals. Those migrants who stayed introduced previously unknown forms of individual land use to the Amazon. While cash crops were introduced to the south and northeast of Brazil, cattle were introduced to the Amazon. Already at that time, the occupation of the Amazon was encouraged by the Portuguese state but realized by private initiative, often funded by gold rushes or other extractive activities. In short, the vast hinterlands of the Amazon became populated by adventurous migrants seeking a more prosperous future. Because they could rely only on their own capabilities and on the resources nature had to offer, an interesting pattern of natural resource and land use arose: each locality developed a major commodity for exchange or trading as well as a highly diversified range of further products, mainly derived from nature, to complement the chief commodity and to cushion individual livelihoods. Ever since, new economic cycles have continued to introduce layers to the Amazonian logic of multiply rooted survival strategies: most recently the additional income 
has derived not only from locally sourced products but from jobs in nearby cities as well (Schönenberg 2011). According to this logic, the socioeconomic resilience of the Amazonian populations has remained high, despite rapid transformations. Only when too many elements are eliminated at once can whole regions lose their social cohesion and enter a spiral of short-lived informal survival strategies that render them socially, ecologically, and economically vulnerable (Schönenberg 2002, Osuna et al. 2014). In this context, the major change we are currently observing and analyzing in our research region is the destruction of economic fallback sources through the takeover of entire tracts of land by agro-industrial production and the resulting transformation of the socio-cultural livelihood patterns of local populations this entails. Unlike the end of the rubber boom or the depletion of a gold or iron ore mine, when the cattle, soy, corn, and palm oil boom comes to an end, there will be nothing left to fall back on, since the natural landscape will, to a great extent, have been irretrievably destroyed. In summary, while it is not unusual for the region to pass through a dominant economic cycle and to be heavily dependent on external market forces, what is new is for the region to lose its very ability to survive on what nature provides additionally.

When the Brazilian state started the occupation of the Amazon via highways in the 1960s, 100-km areas alongside both sides of the highways were declared federal territory; additionally, indigenous territories, natural reserves, and national forests are predominantly under federal jurisdiction. The legacy of those legislations is the often diffuse institutional double structure of federal and state institutions being responsible for land and environmental governance.

Referring to this general pattern, the history of occupation of the Amazonian lands around Highway-163, based on our own biographical research (Schumann et al. 2015), can be subdivided in to three phases: Highway- 163 has been under construction since 1973 and currently, has been undergoing paving for almost 10 years. The primary structure of the occupation of Highway-163 (1973-1983) followed the same 100-km pattern (explained above), and those $100-\mathrm{km}$ pieces of land were supposedly "liberated by the military" and thus are under federal jurisdiction. The pioneer families from Paraná and Rio Grande do Sul, who came with some capital to start their new lives, arrived in the region in this first phase and have been acting as opinion leaders to this day. From the early 1980s the ambitious military projects in Amazonia entered into crisis; for approximately 10 years (1983-1993) the state retreated almost completely from the region. To this second phase can the powerful pioneer spirit that characterizes the region and its decision making be attributed. From 1988, when the new Brazilian Constitution with its progressive indigenous and environmental law was drafted and especially from 1989 when the National Plan for Agrarian Reform (PNRA) became effective, the region of Highway-163 began to feel direct and indirect impacts of often inadequate state regulation. After 1992, with the UNEP-conference in Rio de Janeiro, the ECO92, Amazonia finally entered into globalized channels being shaped by international conventions (CBD, Climate, Forests) and programs shaped by the ideas of sustainable development (e.g., Pilot Program to Conserve the Tropical Rainforests in Brazil - G7, active 1992-2012). In this third phase, the Plan for a SustainableBR-163 (Schönenberg et al. 2015) tried to reconcile between the growing agroindustry (soy in Mato Grosso, cattle in Pará) and the decreed sustainability strategies. All this had an enormous practical impact on Highway-163: while production of soy, cotton, and cattle grew fast, the federal environmental agency, IBAMA intensified massively its environmental monitoring and sanctioning. What did not change at all, is the quality of information circulating in the region; there are many interpretations and implementations of existing laws and norms. Within this ambiguity, the actors we consider in our story lines make their decisions on land use, investment, and selling. The major unifying factor in the region is the rejection of all state interventions and the bitterness regarding sanctions without technical support. True to this biographical perspective, in our scenarios, we aim at including the protagonists of Highway-163 and their leeway to influence their future.

\section{Brazil today}

The Brazilian state claims to be a developmental state (WooCumings 1999), meaning that it tries to shape society and economy according to its visions of a great Brazilian future. Depending on the societal groups being represented by the state, such developmental visions and their respective governance strategies differ substantially. From 2003 to 2016, the Workers Party (PT) governed the country, trying to promote social justice with a whole set of distributive social policies founded on a conservative economic growth strategy. For our research region, southern Amazonia, this means the unconditional support of large-scale agribusiness, the construction of large dams neglecting the legal consultation mechanisms foreseen in environmental auditing (Hall and Branford 2012), accompanied by a delayed land reform, violent forms of conflict resolution regarding land and natural resources, and impunity, such that in the municipality of Novo Progresso alone, unpaid fines for illegal deforestation have reached more than 400 million Reais. On the other hand, programs like Terra Legal that aim to regulate land use, and implementation mechanisms of the forest code, like Cadastro Ambiental Rural, an environmental licensing program, are chronically underfinanced (Azevedo et al. 2015); additionally, credit lines for climate-smart agriculture like the ABC-program (Carauta et al. 2017) would not consider the specific needs of farmers trying to shift to a climate smart rotation system (Gil et al. 2015). The second major aspect of governmental policies is expansion on the global stage, and this is where environmental and climate policies come in. For the Amazon, such global interactions have resulted in approximately $40 \%$ protected areas, sporadically enforced environmental laws, and constant insecurity in the anticipation of new laws and norms to come (Campbell 2014). The current political practice of land use is further complicated through market demands, climate change, lack of legal certainty, institutional weakness, and corruption, all providing a complex setting indeed for the integration of our interand transdisciplinary knowledge.

\section{MATERIALS AND METHODS}

\section{The Carbiocial scenario-building process}

The objectives of the Carbiocial scenario-building process were manifold and reflect the internal process of knowledge aggregation within the research group. First, we aimed at constructing communicative bridges between and among social and natural sciences by using methodologies that would serve the 
needs of all involved. The social scientists insisted on the actor's perspective on current and future developments and on the integration of local data; the natural scientists needed to find a meaningful pattern to orient the multiple disciplinary research approaches and translate them to the simulation models within Carbiocial. In this context one essential application was the quantitative analysis and visualization of past and future landuse change (e.g., deforestation, agricultural intensification), which is known to heavily impact greenhouse gas emissions as well as biodiversity (Chaplin-Kramer et al. 2015). We will therefore discuss the process of land-use change later in the paper. As a project of the applied sciences we conceptualized the scenario method as an instrument for informed stakeholder dialogs and a framework for designing a multilevel decision-support tool. The scenario-building process as such included three steps. The first step was the development of story lines that describe different future development pathways of southern Amazonia (explorative scenarios). In the second step the story lines were translated into quantitative information on socioeconomic factors that are important drivers of land-use change, e.g., population growth or agricultural production. Finally in the third step the spatially explicit land-use models LandSHIFT and alucR were applied to calculate the resulting land-use change patterns within southern Amazonia on the regional and landscape scale.

\section{Development of story lines}

In a first step, we agreed that the linkage between qualitative social science data and numerical data required for modeling has to be considered carefully. Here, we chose a blend of all economic, biophysical, and social factors that were needed as input for the two land-use models involved as a guiding principle for all scenarios and the development of story lines.

In a second step, it was decided that the aggregation of qualitative data alongside the logic of the previously enumerated input data would provide the necessary interface to the models; to limit bias and to include decades of qualitative research in Amazonia, all available Amazonian experts in Germany ${ }^{[1]}$ were invited to support the Carbiocial-team in its effort to supply content to the four story lines in a day-long and quite controversial brainstorming session. During the process of story line development the participating social science colleagues were provided with a list of all drivers and were asked for their opinion as to how these aspects would unfold within the respective scenarios. As a result each story line now included respective verbal descriptions that could serve as a starting point for the quantification process. It became clear that multiple trajectories for different Amazonian subregions are imaginable and that the situation at Highway-163, alongside the soy export corridor, is quite specific. The rigid orientation toward the input factors of the models in place, namely, population, agrarian production, livestock, agrarian and environmental policies, protected areas, infrastructure, and impact of climate change/mitigation/ adaptation helped to organize the abundant knowledge toward workable and compatible data; the approach to go along with the data-necessities of the models maintained the definition-power with the Amazonian experts instead of handing it in to the calibration of the modeller's.

The main results of this exercise were four story lines that depict plausible development pathways for the study region until 2030 , with one being the baseline scenario. The respective narratives were drafted by the Carbiocial project team members based on the discussions of the expert meeting. Afterward the results were translated into Portuguese, the story lines were discussed with about 30 representatives of governmental and nongovernmental institutions in Brasília, Mato Grosso, and Pará to assess their plausibility, and modified accordingly (list in Appendix 1). The depth of the respective debates varied according to the time budget of the institutional representatives. To complement the voice of missing local stakeholders, we incorporated discussions during field days and data from qualitative and biographical interviews that referred to future perspectives. Because of the spatial distribution of research sites and the multitude of Carbiocial and Carbioma interactions, (see Fig. 1), the feedback loops with Brazilian partners and stakeholders at various levels of involvement lacked a certain degree of continuity and happened sometimes rather arbitrarily. One lesson for future research is that a stronger investment in the outcome might have materialized had all co-operation and participation in the research process been negotiated and institutionalized at an early stage of the project. In our position, we genuinely tried to incorporate all available data into our story lines and received predominantly positive feedback during our feedback tour.

Fig. 1. Stakeholder and partner.

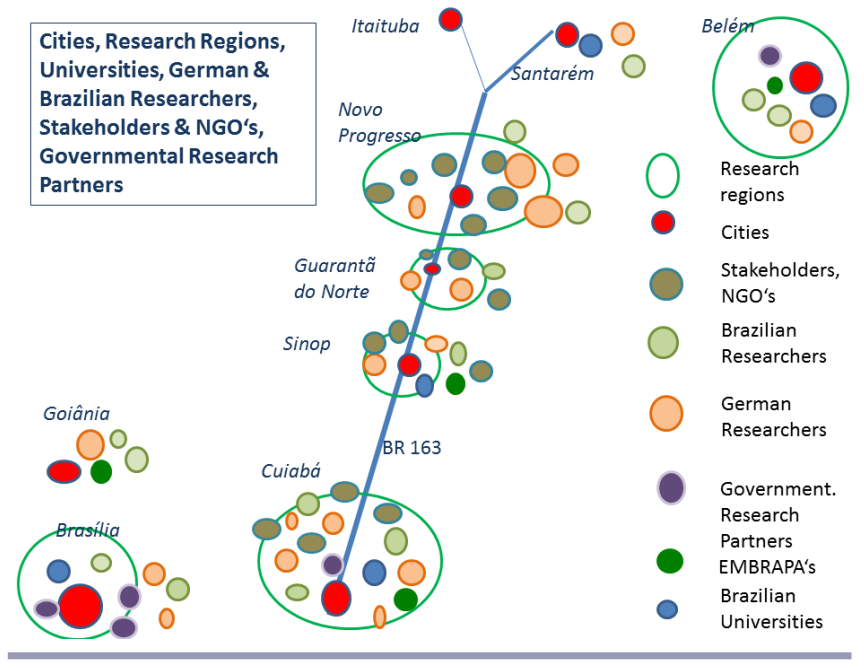

From qualitative to quantitative

Based on the story lines for each scenario a set of land-use drivers was identified to quantitatively describe the evolution of key factors until 2030. These key variables were derived from the analysis of deforestation drivers by Lambin et al. $(2003)^{[2]}$ but were already oriented toward the input data requirements of the land-use change models. Hence, they were subdivided into three topics: population change, agricultural development, and landuse policy according to the data input requirements of the landuse change model.

The translation process was mostly based on expert-opinion and less formalized than, for example, the fuzzy cognitive maps approach described by Kok et al. (2015). In the first step statements from each story line regarding the three topics were extracted and interpreted in light of their potential meaning for 
the land-use modeling process. In the second step this qualitative information was translated either into numerical data describing the trends of population development, agricultural production, and productivity changes, e.g., crop yield increases, or, in case of land-use policy, into rules that were integrated into the land-use models. This process was supported by communication within the Carbiocial-team, including communication with the respective Brazilian partners of the subprojects (see Fig. 1).

\section{Modeling land-use change}

We applied two nested, spatially explicit land-use models to generate a set of land-use maps from 2010 until 2030 that depict the effects of the specified social and economic developments at the state level and along Highway-163. The objective of this modeling and mapping exercise was to support scenario developers and decision makers as potential users to better interpret the plausibility of the scenario assumptions and to evaluate the resulting problems from the expansion of agricultural productive land at the expense of natural habitats for society and the economy. Moreover, these new layers of information facilitate further model- or GIS-based analysis of land-use change impacts on the regional carbon balance or the loss of biodiversity (e.g., Chapin et al. 2000, Fearnside et al. 2009, Chaplin-Kramer et al. 2015) and may act as a test bed for the development of strategies toward sustainable land management. The linkage between the two modeling approaches on different spatial scales is aimed to improve the consistency of the results, while the advantages of addressing land-use change at different scales are preserved. Developments such as population changes or the increases of export orientation of agricultural production can be more easily estimated at a state level, while land-use conversion restrictions due, for example, to the Soy Moratorium can be defined more explicitly within the landscape-level scenario.

Land-use maps were generated for two spatial scale levels: (1) for the two states Mato Grosso and Pará (MT/PA) with a cell size of $900 \mathrm{~m} \times 900 \mathrm{~m}$ and (2) for the Highway-163 corridor with a cell size of $90 \mathrm{~m}$ x $90 \mathrm{~m}$ (see Fig. 2). For this purpose a database was developed that comprises census data for the population and the agricultural sector as well as different types of GIS maps. The land-use data comprised the TerraClass, a multiannual classification of land use within the Amazon biome and the global MODIS land cover product (Friedl et al. 2010, Almeida et al. 2016). The census data was obtained from the Instituto de Pesquisa Econômica Aplicada (IPEA) database on macroeconomics, social and agricultural statistics. Data for the urban and rural populations were available for the period from 1940 to 2010 at the state level. Yearly data at the municipality level were available for livestock numbers (heads of cattle, goats, and sheep) for the period from 1974 to 2007 and for crop production for the period 1973 to 2010 .

Datasets from 2013 on protected areas were acquired from the Ministério do Meio Ambiente (MMA), including areas of strict nature protection (proteção integral), sustainable use (uso sustentável), and indigenous areas (Terras Indigenas). Information on military areas was acquired from the Zoneamento Ecológico-Economico da Rodovia BR-163 (ZEE; Embrapa 2013, http://zeebr163.cpatu.embrapa.br/index.php). For a detailed analysis of the Highway-163 corridor we additionally included Riparian Protected Areas (RPA) estimates for a river dataset provided by the Agência National de Águas (ANA).
Fig. 2. State level land-use scenarios.

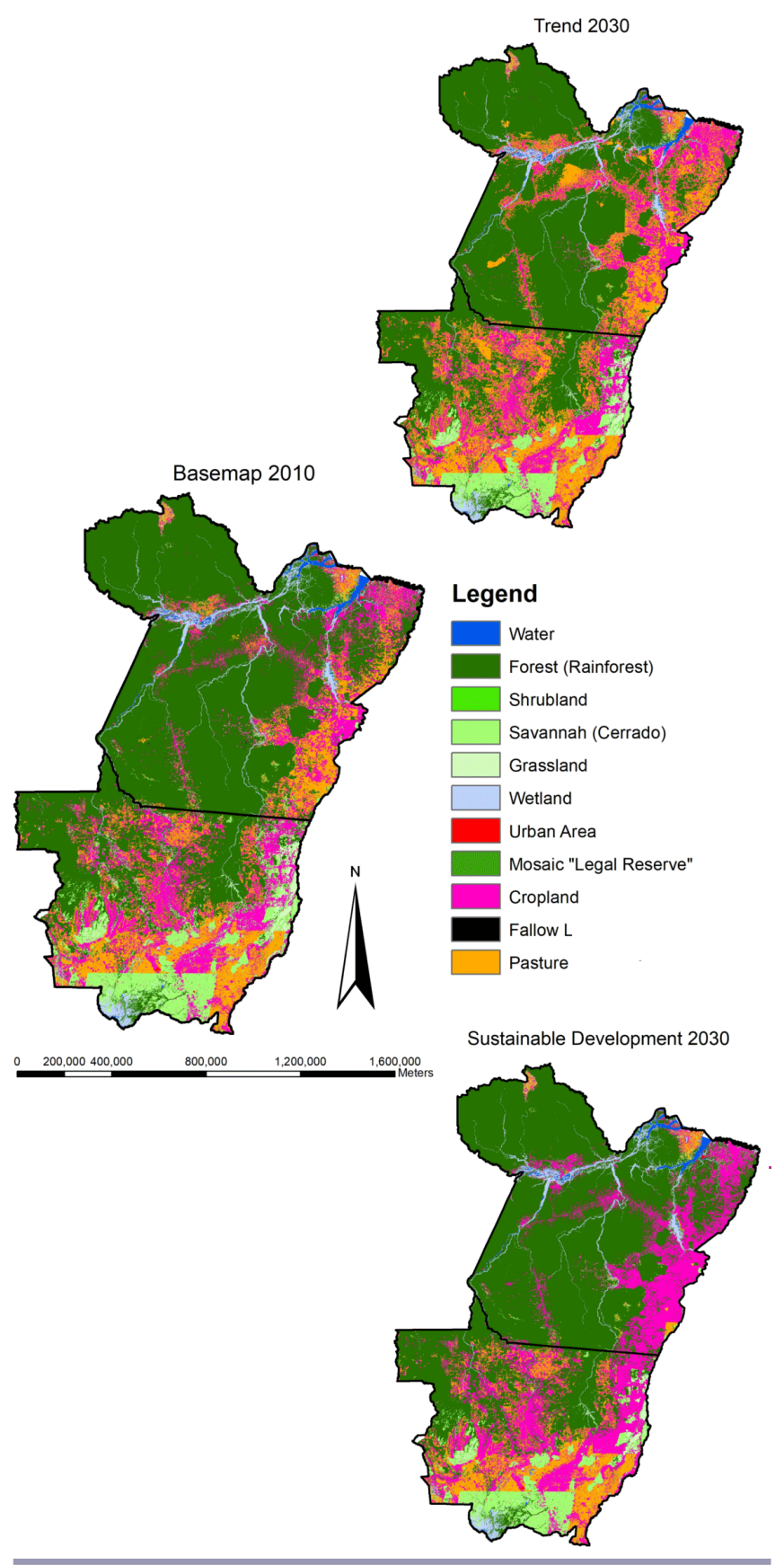

Land-use and land-cover change (LULCC) at the state level were simulated with the spatially explicit LandSHIFT model. The model is fully described in Schaldach et al. (2011) and has been tested in different case studies for Brazil (Lapola et al. 2010, 2011). A comprehensive analysis of the impacts of future land-use change on the emission of greenhouse gases in our study region is described in Goepel et al. (2017). In this paper we describe the model outcomes for the two most contradictory scenarios (Trend and Sustainable Development) to illustrate the linkage between story lines and spatial simulation. LandSHIFT is based on the concept of land-use systems (Turner et al. 2007) and couples 
components that represent the respective anthropogenic and environmental subsystems. The model simulates the spatiotemporal dynamics of settlement, cropland, and pasture by regionalizing their state-level drivers to the raster level in 5-year time steps. Model drivers include the numerical data on human population growth (Topic: "population"), livestock numbers, agricultural production, and productivity changes (Topic: "agricultural development"). Policy settings include the restriction of land-use change in protected areas and the model rules that allow for the conversion of forest and Cerrado (savanna) into agricultural and settlement areas. Moreover, information about the development of road infrastructure influences the attractiveness of a particular cell for being converted into agricultural land (Topic: land-use policy). Cell-level information comprises the state variables "land-use type" and "human population density" as well as a set of parameters that describe its landscape characteristics (e.g., terrain slope), road infrastructure, and zoning regulations.

Nested within the state level model, the alucR model was applied to the Highway-163 corridor to provide annual scenarios starting in 2010 (Gollnow et al. 2017). The amount of land use change along the Highway-163 was passed in detail from the state level model to the Highway-163 model.

\section{RESULTS}

We describe the results of our inter- and transdisciplinary efforts: the integration of Carbiocial story lines toward the quantification of the main drivers of land-use change and the visualization of the resulting land-use changes with simulation models. These results were only possible because our interdisciplinary interest went so far as to mutually integrate each other's methodologies in clustering information and to modify the story lines according to the additional information received during the institutional feed-back-tour.

\section{Story lines}

The four projective story lines describe different pathways of future regional development within the two states (see Fig. 3). Because of the strong linkages of the agricultural sector of southern Amazonia to global markets, e.g., exports of soy and meat, in the past decades (Richards et al. 2014) it was necessary to include this dependency as an important determinant within our scenarios. Also, we considered law enforcement of the existing legal situation-more than $40 \%$ of Amazonia Legal ${ }^{[3]}$ is an officially protected area-as crucial for future development. Reflecting the discussions of the expert-workshop on the very progressive environmental and indigenous legislation on paper, the presence of an active civil society and a robust institution of public prosecutors, we proposed a potentially viable sustainability scenario (Scenario III) as well. Taking into account the influencing factors of land-use change, in particular, population, agricultural production, agrarian and environmental policies, protected areas, infrastructure, and mitigation/adaptation, the four resultant narratives of the story lines until 2030 are summarized below; the full story lines are included in Appendix 1 . The story lines do not explicitly address the intensity of climate change but assume that the described agricultural development can be achieved under changing climate conditions until 2030.

The "Trend" story line is used as a reference for future land-use change. It is based on a forward projection of growing demand for agrarian products, a continuation of the conversion of natural ecosystems, the technical and social consolidation of Highway-163 and local populations, as well as the further intensification of agrarian production and sporadic law enforcement.

Story line I describes a scenario of "Legal Intensification." It assumes a growing demand for agrarian products, but with effective law enforcement preventing the illegal conversion of natural ecosystems; the technical and social consolidation of Highway-163 and its populations will include heightened intensification of agrarian production with regard to increased production as well as productivity; law enforcement of social and environmental law will be effective under conditions of continuing climate change.

Fig. 3. Scenario logic of Carbiocial.

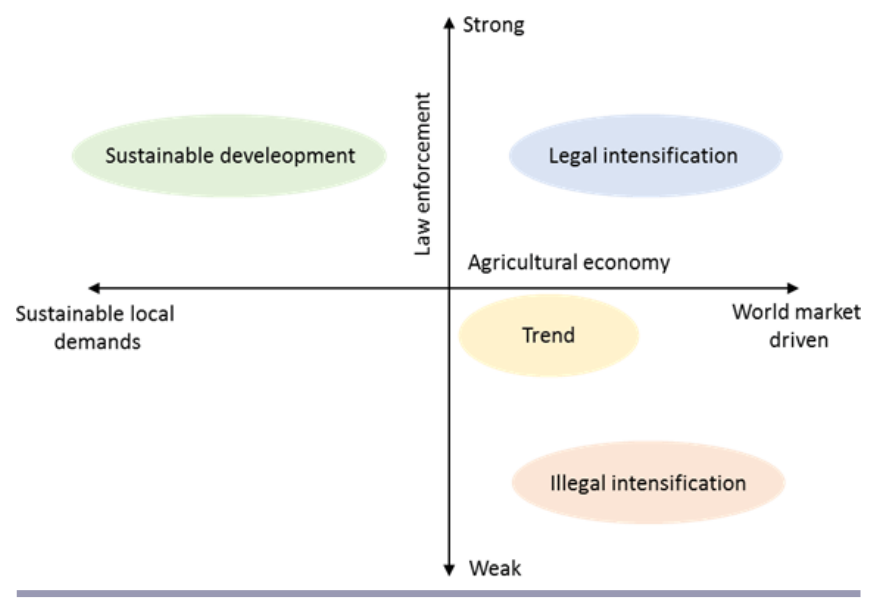

Story line II describes a scenario that is characterized by "Illegal Intensification." As with Story line I it assumes a growing demand for agrarian products, but with only very sporadic law enforcement, which will lead to the further conversion of natural ecosystems; the technical and social consolidation of Highway-163 and its populations will include a high intensification of agrarian production, specifically increased production.

Storyline III describes a "Sustainability" scenario that is the most complex, because it projects a completely new local, national, and global society, albeit within possible legal and societal parameters: Amazonian society will enjoy a social model where participation, citizenship, and the enforcement of existing laws are complemented by further adequate laws, with an inclusive economic system, food sovereignty, the protection of resources with participatory monitoring, the political will to initiate local, inclusive, and sustainable development in favor of the majority of the population, available knowledge and technical resources, a growing national and global demand for certified agrarian goods, access to global financing for sustainable economics, regional identity, support of value chains, diversity and resilience, alternative agrarian counselling, and clarification of land rights or land reform in the project region. Below, the entire process of model integration will be exemplified with reference to this sustainability scenario. 


\section{Quantification of land-use drivers}

The input data required by the land-use models was classified into the three categories, human population, agricultural development, and land-use policy.

\section{Human population}

Under the Trend, Illegal Intensification, and Legal Intensification scenarios, human population changes until 2030 were calculated in line with the observed trend from 1973-2000. Trend extrapolation was calculated with the least squares method (Rao et al. 1999). For example, concerning the story line assumption "population growth is going to continue according to past observed trends." Data on past population growth had to be on a spatial resolution of at least federal state level in order to be applicable directly (without further disaggregation) as a basis for the extrapolation of past trends on the federal state level. Therefore, data on past observed population growth was taken from the IBGE database (IBGE 2013, http://www.ibge.gov.br/ estadosat/index.php) with a spatial resolution on the municipality level for the period from the year 1973 to the year 2000 and aggregated (summed up) to the federal state level. Data from the FAO database for instance was only available on the country level. This data would consequently have to be disaggregated to the federal state level, which would have increased uncertainty in regard to the final modeling results (land-use maps). A trend function was fitted to the observed past population development (reference period 1973-2000) per federal state and extrapolated until the year 2030. In Pará this resulted in a population increase from 6.9 million people in 2010 to 9.3 million people in 2030 while in Mato Grosso we found an increase from 2.7 million to 3.7 million people during that period.

In contrast, the story line of the Sustainability scenario assumes that population growth in Mato Grosso and Pará slows, mainly because of lower immigration from other parts of Brazil. This slowdown is more intensive in Mato Grosso. In the case of Pará it is also present but is dampened by job opportunities created because of the pioneer dynamics of the agricultural frontier and hydroelectric dams. The population growth rate was adjusted by $-10 \%$ for Mato Grosso and $-5 \%$ for Pará for every five years. The numbers for both scenarios are shown in Table A1.5.

\section{Agricultural development}

The assumptions regarding the development of agricultural production and yield increases in the four scenarios are summarized in Table A1.6 and Table A1.7. In the Trend scenario the international and national demand for agricultural goods and commodities increases in line with previous trends (1973-2000). Consequently the estimates for future crop production, livestock numbers, and human population are derived by statistically extrapolating the respective census data, again using the least squares method. Information on crop yield increases until 2030 through technological advances, e.g. plant breeding or improved agricultural management, and are derived from a global scenario analysis with the economic trade model IMPACT (Rosegrant 2012) conducted in the context of food security research (Vervoort et al. 2013).

To assess the plausibility of the Trend assumptions, we compared the calculated production data for 2030 with the U.S. Department of Agriculture baseline scenario for Brazil (USDA ERS 2015). The results (Table 1) show that our estimations are of the same order of magnitude as the USDA projection.
Table 1. Comparison of the "Trend" scenario with the U.S Department of Agriculture (USDA) baseline scenario.

\begin{tabular}{|c|c|c|c|}
\hline & \multicolumn{3}{|c|}{$\begin{array}{l}\text { Relative change of agricultural production (2010 } \\
\text { 2030) }\end{array}$} \\
\hline & Sugarcane & Maize $^{\dagger}$ & Soybean ${ }^{\star}$ \\
\hline $\begin{array}{l}\text { USDA baseline } \\
\text { Carbiocial } \\
\text { Trend-scenario }\end{array}$ & $\begin{array}{l}+40.8 \% \\
+40.0 \%\end{array}$ & $\begin{array}{l}+55.2 \% \\
+44.4 \%\end{array}$ & $\begin{array}{l}+139.6 \% \\
+109.9 \%\end{array}$ \\
\hline \multicolumn{4}{|c|}{$\begin{array}{l}\text { "USDA baseline scenario: aggregated crop class "other grains" wi } \\
\text { maize as main crop. } \\
\text { "USDA baseline scenario: aggregated crop class "oil seeds" with } \\
\text { soybean as main crop. } \\
\text { \$ mean production increase over both federal states. } \\
\text { Source: USDA baseline (USDA ERS } 2015 \text { ); own calculations. }\end{array}$} \\
\hline
\end{tabular}

Both the Legal Intensification and the Illegal Intensification scenarios assume that future agricultural production shows an even stronger increase than the historic trend, mainly driven by growing demand from Asian countries, which are expected to experience rapid population growth in combination with increasing per capita income (Kalimili and Fantom 2016). The Asian market resembles the most important export market for commodities produced in Brazil with close to $25 \%$ of the total Brazilian exports. Other important export destinations are the European Union $(18.7 \%)$ and the United States of America (12.1\%) as well as Argentina (6.3\%; WTO 2016). The additional increase in agricultural production is related to estimates of future population growth in the four most important export countries for agrarian products from Brazil in Asia: China, Thailand, Japan, and South Korea. Looking at these countries, China is the largest market, with a share of $88.6 \%$, while Thailand accounts for $6.2 \%$, Japan for $2.7 \%$, and South Korea for 2.1\%. The weighted cumulative changed rates of population growth in the selected Asian countries were multiplied with the increased rates of agricultural production in Mato Grosso and Pará. This resulted in an adapted production growth rate that accounted for increasing agricultural production as well as the export-induced production increases generated by a growing population and rising per capita income in Brazil's main Asian export destinations. For example, if the population growth rate in China is $10 \%$ above the production growth rate in Mato Grosso or Pará, we experience an additional increase of agricultural production in the Brazilian federal states of $8.6 \%(10 \% * 88.6 \%)$. Crop yield increases are similar to those in the Trend scenario.

The central aspect of the Sustainability scenario that affects agricultural production is a general shift to a more vegetarianoriented diet based on the recommendations from the World Health Organization (WHO; e.g., Amine et al. 2002, Srinivasan et al. 2006). To estimate future reduction potentials of meat consumption we compared current meat consumption (Table 2) with the recommended amounts of meat consumption following the Harvard Medical School for Public Health.

The Harvard Medical School for Public Health recommends about $10 \mathrm{~g}$ beef, $10 \mathrm{~g}$ pork, and $46.6 \mathrm{~g}$ of chicken and eggs per day, which is a total of $66 \mathrm{~g} / \mathrm{d}$ animal products (Stehfest et al. 2009). Consequently the average yearly intake of meat should not exceed $22.3 \mathrm{~kg}$ per person (Stoll-Kleemann and O'Riordan 2015). 
Table 2. Food consumption of animal products in Brazil.

\begin{tabular}{lcccccc}
\hline \hline Year & $\begin{array}{c}\text { Total calorie } \\
\text { supply [kcal/c/d] }\end{array}$ & $\begin{array}{c}\text { Share animal } \\
\text { products [kcal/c/d] }\end{array}$ & $\begin{array}{c}\text { Percentage animal } \\
\text { products }\end{array}$ & $\begin{array}{c}\text { Total consumption } \\
\text { animal products [kg/c/y] }\end{array}$ & $\begin{array}{c}\text { Total consumption } \\
\text { animal products [g/c/w] }\end{array}$ & $\begin{array}{c}\text { Total consumption animal } \\
\text { products [g/c/d] }\end{array}$ \\
\hline 1999 & 2867 & 629 & $21.94 \%$ & 76.5 & 1471 & 1563 \\
2004 & 3085 & 680 & $22.04 \%$ & 81.3 & 1640 & \\
2009 & 3173 & 737 & $23.23 \%$ & 85.3 & 1558 & 222.62 \\
average & 3042 & 682 & $22.40 \%$ & 81.0 & & \\
\hline Source: FAOSTAT 2017. & & & &
\end{tabular}

Comparing the recommended to the average meat consumption in Brazil, a mean reduction potential of calorie intake from animal products of $156 \mathrm{~g} /$ day per person was estimated (-70\%). Based on these findings we assume that meat production in the two states decreases by $70 \%$. At the same time, we assume a reduction in the share of soy exported by $10 \%(70 \%-60 \%)$ because of decreased international fodder exports coupled with increased soy exports on account of worldwide substitution for meat consumption. We model the process of dietary transition as a gradual process occurring over a 20-year period (2010-2030). The emerging nutritional gap resulting from a reduction in meat consumption of $530 \mathrm{kcal} /$ day per person (in light of the WHO recommendation per person of $\sim 2512 \mathrm{kcal} /$ day) needs to be substituted with calories from other sources. Following the approach of Stehfest et al. (2009), soy protein fills $60 \%$ of missing calories. According to the recommendations of the World Cancer Research Fund, fruits and vegetables should account for $13 \%$ of the replacement, with the remaining share made up of pulses, as has been summarized in Table 3.

Table 3. Quantities of commodities replacing animal product consumption.

\begin{tabular}{|c|c|c|c|c|c|c|}
\hline \multirow[t]{2}{*}{$\begin{array}{l}\text { Commo- } \\
\text { dity }\end{array}$} & \multirow[t]{2}{*}{$\begin{array}{l}\text { Ratio } \\
\mathrm{kcal} / \mathrm{g}^{\dagger}\end{array}$} & \multirow[t]{2}{*}{$\begin{array}{c}\text { Share of } \\
\text { meat } \\
\text { substitution }\end{array}$} & \multicolumn{2}{|c|}{$\begin{array}{l}\text { Additional } \\
\text { requirement per } \\
\text { capita/d } \\
\end{array}$} & \multicolumn{2}{|c|}{$\begin{array}{l}\text { Additional } \\
\text { requirement } \\
\text { t/y }\end{array}$} \\
\hline & & & kcal & $\mathrm{g}$ & $\mathrm{MT}^{*}$ & $\mathrm{PA}^{\S}$ \\
\hline Soybean & 1.8 & $60 \%$ & 318 & 177 & 196,084 & 489,773 \\
\hline Pulses & 3.37 & $27 \%$ & 143 & 43 & 47,636 & 118,984 \\
\hline Fruits & 0.4 & $6.5 \%$ & 34.5 & 92.5 & 102,473 & 255,955 \\
\hline Vegetables & 0.25 & $6.5 \%$ & 34.5 & 148 & 163,957 & 409,528 \\
\hline $\begin{array}{l}{ }^{\dagger} \text { FOASTA } \\
{ }^{\ddagger} \text { Mata Gro } \\
{ }^{\S} \text { Pará } \\
\text { Source: ov }\end{array}$ & $\begin{array}{l}\text { T } 2017 \\
\text { psso }\end{array}$ & & & & & \\
\hline
\end{tabular}

Finally we adjusted agricultural production taking into account the decrease in population growth described in the Sustainability story line. Accordingly the growth rate of agricultural production for domestic markets, amounting to $57.5 \%$ of total production (MAPA 2012) was reduced by $-10 \%$ (Mato Grosso, MT) and $-5 \%$ (Pará, PA) respectively, compared to the Trend scenario.

As noted in the story line, crop yields increase faster in the Sustainability story line than in the other scenarios. An additional $7.5 \%$ crop biomass per hectare was assumed to be realized for each time step.

\section{Land-use policy and road infrastructure}

As pointed out earlier in the land-use models applied to our study, land-use policy was integrated either as a constraint against land- conversion in designated areas, e.g., nature protection, or as a factor prohibiting (or not prohibiting) the conversion of a specific land-use type, e.g., forest. Road infrastructure typically influences the attractiveness of a cell for urbanization or agricultural development. Whenever there were specifics of one of the two scale levels and extensions of study areas, namely the state level (MT/Pará) and the Highway-163 corridor, we specified these separately for LandShift and alucR, respectively.

In the Trend scenario, natural land that is not protected can be converted into agriculture and settlement area. Moreover the improvement of Highway-163 increases the likelihood that cells near this road are transformed into agriculture (Table A1.1).

These assumptions are also valid for the Legal Intensification scenario, but natural land that is converted between 2010 and 2030 is, in contrast, only partly used for agriculture. According to the new Brazilian forest code, $80 \%$ of each cell should remain forest (Soares-Filho et al. 2014; Table A1.2). These areas were classified as Mosaic land use.

The policy settings for the Illegal Intensification scenario weaken the protection status of natural land within designated areas. Although the conversion of natural ecosystems within indigenous and military areas is still prohibited, the conversion of forest and Cerrado within other types of protected areas is allowed (Table A1.3).

The most rigorous protection of natural land is modeled in the Sustainability scenario. In addition to natural land within protected areas, also forest outside their boundaries is fully protected and cannot be converted into agriculture between 2010 and 2030 (TableA 1.4).

\section{Visualization of land-use change}

On a state level the land-use maps generated with the LandSHIFT model show clear differences between the Trend and the Sustainability scenarios (see Fig. 4). Under the Trend scenario in Pará the increasing production of agricultural commodities leads to an expansion both of pasture $\left(+102,271 \mathrm{~km}^{2},+99.6 \%\right)$ and cropland $\left(+24,231 \mathrm{~km}^{2},+16.4 \%\right)$. This expansion comes at the expense of tropical rain forest $\left(-113,370 \mathrm{~km}^{2},-11.5 \%\right)$ and Cerrado vegetation $\left(-12,879 \mathrm{~km}^{2},-52.2 \%\right)$. The majority of these land-use changes are located in close proximity to development corridors (BR-163, BR-230) and along the eastern state border. In Mato Grosso pasture expands by $84,590 \mathrm{~km}^{2}(+50.3 \%)$. In contrast, cropland decreases by $18,334 \mathrm{~km}^{2}(-8.3 \%)$ as crop yields due to progress in terms of agricultural management practices in Mato Grosso increase at a higher rate than agricultural production demands. The recent trend away from an agricultural expansion and massive deforestation toward agricultural intensification in Mato Grosso (Macedo et al. 2012, Cohn et al. 2014, Gollnow and 
Lakes 2014) confirm the simulated land-use dynamics. Altogether $30,136 \mathrm{~km}^{2}(-8.4 \%)$ of rain forest and $34,364 \mathrm{~km}^{2}(-20.1 \%)$ of Cerrado are converted.

In the Sustainability scenario the effects of lower meat consumption and the shift to a vegetarian diet become prevalent. Pasture area in Pará decreases considerably, by $89,059 \mathrm{~km}^{2}$ $(-86.7 \%)$. At the same time cropland increases by $92,995 \mathrm{~km}^{2}$ $(+53.9 \%)$. Because the majority of this increase is located on former pasture land, only an additional area of $3518 \mathrm{~km}^{2}(-15.1 \%)$ of Cerrado is transformed to cropland. Because of the effective protection of rain forests, area covered by pristine rain forests remains constant. Similar to the Trend scenario, new cropland is located in regions west of Rio Tocantins, along the development corridors (BR-163, BR-230) and around the shores of the Amazon in western Pará in close proximity to Santarém. In Mato Grosso the same trends can be observed but they are less pronounced. Although pasture area only slightly decreases by $2454 \mathrm{~km}^{2}(-1.5 \%)$, cropland expands by another $45,093 \mathrm{~km}^{2}$ $(+20.4 \%)$ mainly at the expense of Cerrado vegetation $(-36,727$ $\mathrm{km}^{2},-21.5 \%$ ). As in Pará the forest area remains constant. Altogether the Sustainability scenario is characterized by a significantly lower loss of natural vegetation than the Trend scenario. The greater expansion of cropland due to the increased demand for food crops is more than compensated for by the decline of pasture.

Fig. 4. Carbiocial study area at Highway 163.

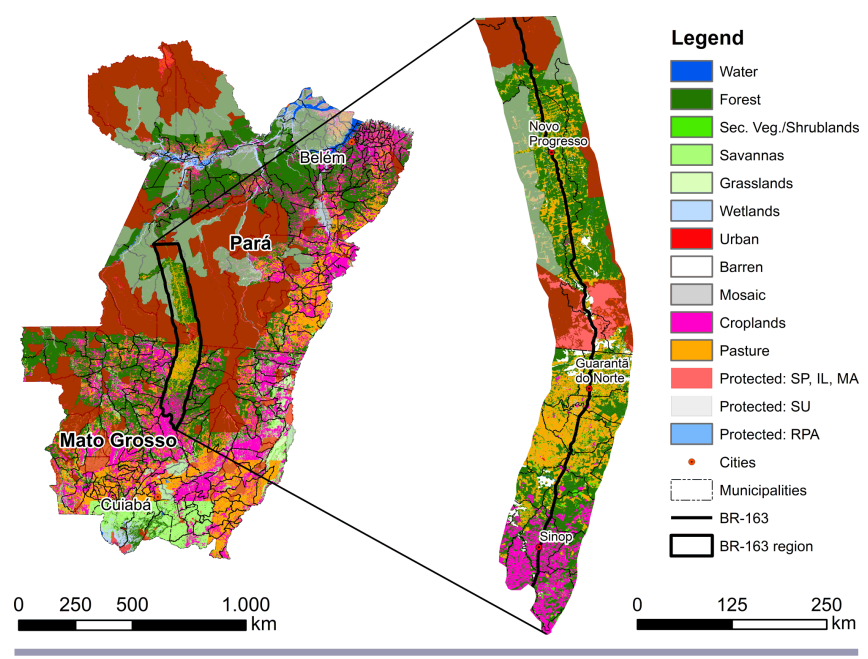

\section{Landscape level}

The Highway-163 corridor, connecting Mato Grosso and Pará, was one of the hotspots of land-use change within the State-level scenarios (see Fig. 4). Passing the demand calculated from LandSHIFT into alucR for the landscape-level scenario analysis along the Highway-163 corridor confirms the very dynamic land use change processes that are expected for the two studied future scenarios: the Trend and the Sustainability scenario. The overall increasing agricultural demands following the Trend scenario resulted in increases of pasture areas along the Highway-163 corridor, while developments of intensification and the expansion of croplands in other region of Mato Grosso and Pará led to a reduction of cropland areas along Highway-163. Pasture land increased by about $9747 \mathrm{~km}^{2}(12.8 \%)$, and cropland decreased slightly by $-248 \mathrm{~km}^{2}(-\mathrm{O} .3)$ along the corridor. Expansion dynamics of pasture were strongest in Pará, centered on the Municipality of Novo Progresso (see Fig. 5a) along Highway-163 and in the north of Mato Grosso (see Fig. 5b), where cropland was converted into pasture. But pastures largely expanded into areas of natural vegetation. Expansion of pasture followed the underlying suitability distribution while the riparian protected areas stopped land use expansion in close proximity to rivers. Urban land use was not expected to change along the Highway-163 corridor but has been addressed in more detail in Gollnow et al. (2017). Secondary vegetation growth was mainly located in Pará.

Within the Sustainable development scenario, production demands along Highway-163 changed substantially compared to the Trend scenario. Following the state level model, the Highway-163 corridor was again one of the hotspots of land use change in Mato Grosso and Pará. Within this scenario, cropland expansion turned out to be the main driving factor of land-use change. Croplands expanded by $2111 \mathrm{~km}^{2}(2.8 \%)$ along the corridor. At the same time, pasture areas decreased by $1099 \mathrm{~km}^{2}$ $(-1.5 \%)$ along the corridor. Cropland expansion occurred mainly on pasture areas in the south of the study area (see Fig. $5 \mathrm{c}$ ).

\section{DISCUSSION}

Our findings illustrate an individual approach to developing story lines and scenarios by combining qualitative knowledge and quantitative data from different disciplines and discuss its plausibility with available institutional decision makers. Qualitative story lines for the region were combined with quantitative land-use scenarios to study their regional and local manifestations in space. These results were then discussed again with local and national experts.

Learning from the historic developments and past trajectories within the region allowed for detailed insights into the ongoing land-use change processes in the Brazilian Amazon. The essence of such knowledge was integrated in the land-use change models. One major insight was the incorporation of learning from historic developments, especially, regarding the differentiated steering capacity of the Brazilian state. Hence, we incorporated different degrees of compliance with legal guidelines both into the story lines and the modeling process of future land-use change. The respective quantification and spatial allocation resulted in distinct land-use trajectories within Mato Grosso and Pará until 2030. For the Highway-163 scale, we explicitly addressed different degrees of compliance in the modeling experiment (Trend story line) in that we did not strictly prohibit conservation areas from land-use changes but allowed such changes to occur within a specific time frame (every few years). Another major insight from our historic analyses was the identification of a very heterogeneous planning system and policy constellation that is characterized by contradicting actor groups, institutions, and planning instruments that frequently do not go hand in hand but instead contradict each other and exhibit a high dynamic with a low degree of reliability. Our analyses revealed that it is very difficult to pinpoint the decisive turning points that are important to anticipate. This is why we developed the different story lines and respective scenarios. We believe that only such a multifaceted approach to scenario-building can support the process and 
Fig. 5. Corridor coupled land-use scenarios.

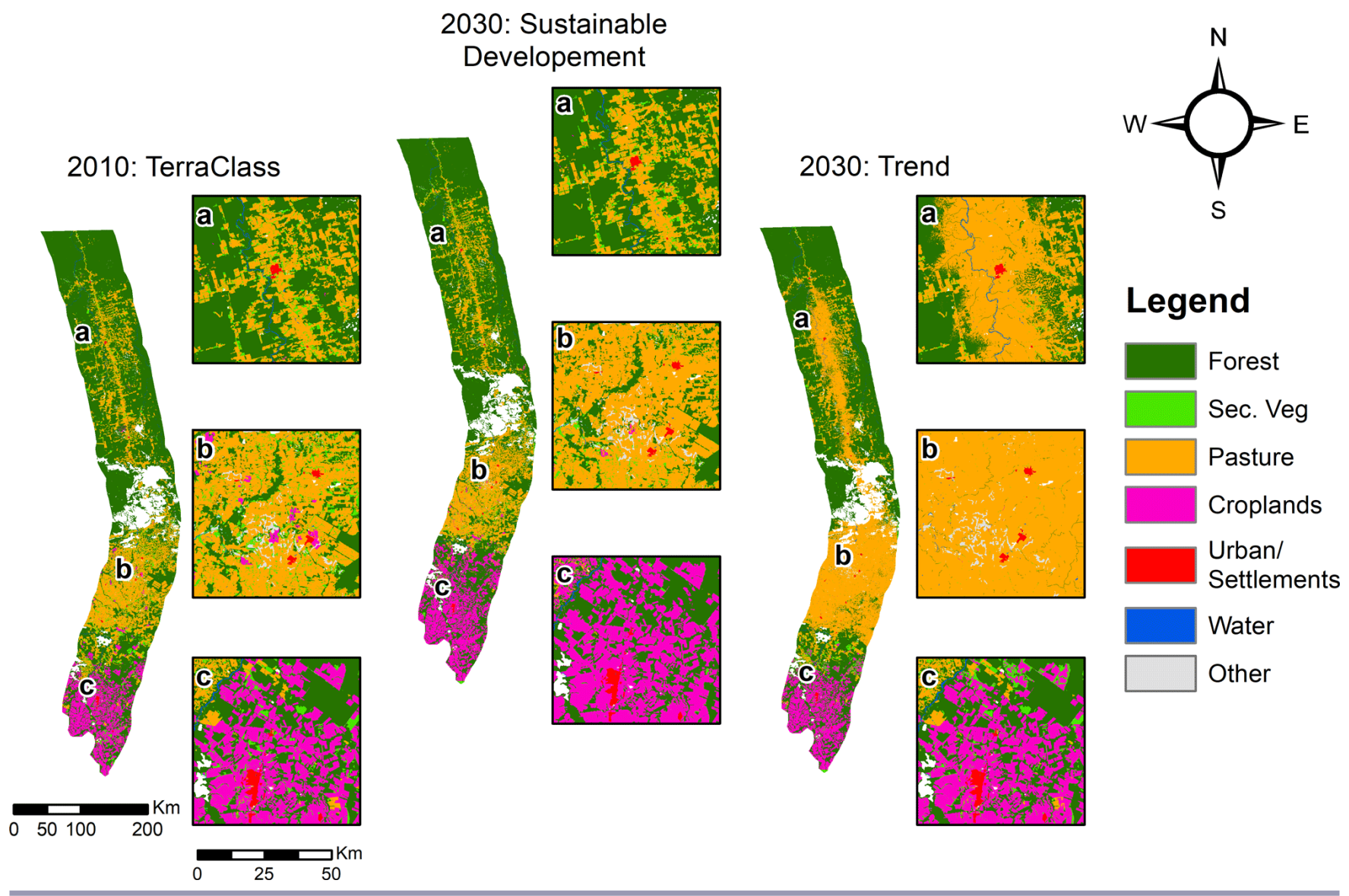

stimulate further discussions between stakeholders to produce a coherent story line for the future. The multiscale approach of the explicit spatial scenario modeling aimed to address the hierarchical structure of land development decisions in the Brazilian Amazon. Although some decisions are clearly driven by global markets, e.g., overall demand for soybeans, others are locally restricted, e.g., new road infrastructure development, implementation of forest code in riparian areas. By addressing both scales in our land-use change scenarios we allow for exploring different processes and developments, as well as their outcomes, in a coherent way.

To incorporate behavioral probabilities by parameterizing the land-use change model according to past observed land-use change dynamics, and thus actor behavior, on the basis of deep historical background knowledge toward the quantification of future scenarios may be considered a daring approach. On the other hand, taking note of and learning from history in the form of past human behavior, especially when planning future research, adds the human dimension to the scenarios and makes the results more viable. The feedback, producing visualized futures in detailed maps that aggregate all data on the landscape level at different scales, opens up new perspectives and possibilities on regional complexities. Additionally, the possibility of visualizing data-rich scenarios in maps provides new opportunities for public participation in planning processes.
With this approach we can therefore augment existing studies that approach future land-use challenges from a theory-driven and generic approach of scenario-building, giving only limited consideration to regional characteristics (Verburg et al. 2013). We are in line with those studies that consider the need to use scenarios for analyzing policy instruments and their consequences in land use in Amazonia (Soares-Filho et al. 2005, Moreira et al. 2009, Aguiar et al. 2016).

The normative guideline for producing applicable scientific results leads to an inter- and transdisciplinary research approach. In fact, the integration of results and the merging of models took place with a view to applicability, although it de facto exceeds the current capacities of Brazilian policy co-ordination. The precondition for achieving such interdisciplinary knowledge integration was a qualitative scientific process: only intensive internal communication among the scientists allows for common, understandable and hence communicable results; the effort of understanding each other within the research group bears communicative implications for external communication, which itself is essential for reaching the goal of applicability.

Inter- and transdisciplinary research inevitably leads to extraordinary communicative efforts: Because disciplinary language and terminology is not practical in such contexts, even complex content must be explained in accessible terms. 
Participants of inter- and transdisciplinary research groups express meanings rather than simple facts and results; they require a jointly constructed research object to which each group member can refer back when reporting new insights (Jahn et al. 2012). Such mutual understanding may lead to oversimplification, or it may lead to the application of holistic approaches. In any case, it remains interesting, time-consuming, and rather risky because "the truth" of the academic discipline is being challenged constantly. In the case of Carbiocial, deep interdisciplinary cooperation led to innovative methodologies, especially with regard to developing future scenarios for the research site in southern Amazonia. However, the process of integrating multiple methodologies led to uncertainties multiplying and becoming more visible than would have been the case with purely disciplinary approaches. Examples include the critical reflection selecting data sources, possible compatibility gaps of methodologies, data interpretation, model calibration, and parametrization from different subject areas and the problematics of scale. Regarding the construction of Carbiocial future scenarios, such uncertainties appear tolerable considering the gain in real-life approximation achieved by combining qualitative with quantitative data via LandSHIFT.

Even though we are able to show the benefits of the systematic approach of developing quantitative and spatially explicit scenarios by building upon transdisciplinary story lines, we are aware of some limitations to our approach. First of all, the selection of experts to formulate the story lines and narratives is decisive for the outcome. We carefully approached our choice of experts; however, the development of the stories is subject to the individuals' opinions and their interaction process at the German expert workshop. Because of some structural constraints in the setup of the project we were also not able to iteratively refine the story lines and evaluate the quantitative scenarios together with the Brazilian experts as was originally planned and proposed. Moreover, because of the nature of the problem under investigation, land-use change, the number and variety of stakeholders and actors in the planning and decision-making process is very high. This resulted in difficulties for our project in narrowing down our scenarios for a specific user group. Although these limitations do need to be considered in this project, we still argue that our methodological approach provides new insights and can be used as a guideline for other projects and case studies with slight modifications. Our findings suggest that in-depth knowledge of the diverging perspectives at a very local level is a fundamental prerequisite for downscaling global scenarios and upscaling local approaches of sustainable land-use management and hence, for producing communicable and applicable results.

\section{CONCLUSION}

In conclusion, and with reference to our research questions, we believe that the proposed process for developing story lines for southern Amazonia strongly benefited from integrating different disciplines with an in-depth knowledge of local processes and histories. We show how we combined qualitative knowledge and quantitative spatial modeling to produce scenario maps of future land-use development. This integration of qualitative and quantitative data on the basis of our own field research into the scenario development process was an important prerequisite for the production of applicable results. By merging the advantages of the awareness of historic processes, of qualitative methods of social and natural sciences on-site, and of quantitative analysis of trends, we were able to develop a comprehensive set of plausible land-use scenarios that offers multiple entry points for informed policy interventions. Due to the complex linkages between social and natural sciences that are inherent to these scenarios, an interdisciplinary group with a transdisciplinary research strategy is required for the construction process. The architecture of our scenarios opens up the possibility to apply models to simulate the outcomes of different land-management policies, including a sustainability scenario that presupposes policy coherence. The degree of depth, complexity, and sophistication of such scientifically grounded imaginary futures are within reach neither of ordinary political and administrative decision makers nor of critical civil society organizations. Hence, we provide an intelligent and transferable methodology to preview the future as an applicable outcome of a complex scientific process.

[1] Gerd Kohlhepp/Geography (Uni Tübingen), Martin Coy/ Geography (Uni Innsbruck), Dörte Segebart/Geography (FUBerlin), Jan Börner/Economy (ZEF/Uni Bonn), Maria Backhouse/Sociology (FU-Berlin), Thomas Fatheuer/Sociology (KOBRA), Jes Weigelt/Political Science (IASS-Potsdam), Benno Prokorny/Forestry (Uni Freiburg), Imme Scholz/Sociology (DIEBonn), Regine Schönenberg/Political Science (Carbiocial/FUBerlin), Michael Klingler/Geography (Uni Innsbruck), Charlotte Schumann/Anthopologist (Carbiocial/FU-Berlin), Korbinian Hartberger/Latin Americanist (Carbiocial/FU-Berlin), Birthe Bretthauer/Latin Americanist (Carbiocial/FU-Berlin), observed by Rüdiger Schaldach/Environmental Systems Research (Carbiocial/USF, Uni-Kassel).

${ }^{[2]}$ Compare: Andersen and Reis (1997), Laurance et al. (2002), Aguiar et al. (2007), and de Espindola et al. (2012).

[3] Amazônia Legal consists of the States of Acre, Amapá, Amazonas, Pará, Rondônia, Roraima, Tocantins, and parts of the States of Mato Grosso and Maranhão; with 5,217,423 $\mathrm{km}^{2}$ it comprises $61 \%$ of Brazilian territory, containing $12.32 \%$ of the Brazilian population.

Responses to this article can be read online at: http://www.ecologyandsociety.org/issues/responses. $\mathrm{php} / 9032$

\section{Acknowledgments:}

We thank the BMBF/FONA for the possibility to work for five years in an interdisciplinary context, which made it possible to come up with our joint results.

\section{LITERATURE CITED}

Aguiar, A. P. D., G. Câmara, and M. I. S. Escada. 2007. Spatial statistical analysis of land-use determinants in the Brazilian Amazonia: exploring intra-regional heterogeneity. Ecological Modelling 209(2-4):169-188. http://dx.doi.org/10.1016/j. ecolmodel.2007.06.019

Aguiar, A. P. D., I. C. G.Vieira, T. O. Assis, E. L. Dalla-Nora, P. M. Toledo, R. A. O. Santos, M. Batistella, A. S. Coelho, E. K. 
Savaget, L. E. O. C. Aragão, C. A. Nobre, and J. P. H Ometto. 2016. Land use change emission scenarios: anticipating a forest transition process in the Brazilian Amazon. Global Change Biology 22(5):1821-1840. http://dx.doi.org/10.1111/gcb.13134

Alcamo, J. 2008. The SAS approach: combining qualitative and quantitative knowledge in environmental scenarios. Developments in Integrated Environmental Assessment 2:123-150. http://dx.doi. org/10.1016/S1574-101X(08)00406-7

Almeida, C. A. D., A. C. Coutinho, J. C. D. M. Esquerdo, M. Adami, A. Venturieri, C. G. Diniz, N. Dessay, L. Durieux, and A. R. Gomes. 2016. High spatial resolution land use and land cover mapping of the Brazilian Legal Amazon in 2008 using Landsat-5/TM and MODIS data. Acta Amazonica 46:291-302 http://dx.doi.org/10.1590/1809-4392201505504

Amine, E., N. Baba, M. Belhadj, M. Deurenbery-Yap, A. Djazayery, T. Forrester, D. Galuska, S. Herman, W. James, J. M Buyamba, M. Katan, T. Key, S. Kumanyika, J. Mann, P. Moynihan, A. Musaiger, A. Prentice, K. Reddy, A. Schatzkin, J. Seidell, A. Simpopoulos, S. Srianujata, N. Steyn, B. Swinburn, R. Uauy, M. Wahlqvist, W. Zhao-su, and N. Yoshiike. 2002. Diet, nutrition and the prevention of chronic diseases: report of a joint WHO/FAO expert consultation. World Health Organization, Geneva, Switzerland. ISBN: 924120916X.

Andersen, L. E., and E. J. Reis. 1997. Deforestation, development, and government policy in the Brazilian Amazon. An econometric analysis. Institute for Applied Economic Research, Rio de Janeiro, Brazil.

Azevedo, A. A., M. C. C. Stabile, and T. N. P. Reis. 2015. Commodity production in Brazil: combining zero deforestation and zero illegality. Elementa: Science of the Anthropocene 3:76. http://dx.doi.org/10.12952/journal.elementa.000076

Becker, B. K. 1982. Geopolítica da Amazônia: a nova fronteira de recursos. Zahar, Rio de Janeiro, Brazil. http://dx.doi.org/10.1590/ $\underline{\mathrm{s} 0103-40142005000100005}$

Campbell, J. 2014. Speculative accumulation: property-making in the Brazilian Amazon. Journal of Latin American and Caribbean Anthropology 19(2).

Carauta, M., E. Latynskiy, J. Mössinger, J. Gil, A. Libera, A. Hampf, L. Monteiro, M. Siebold, and T. Berger. 2017. Can preferential credit programs speed up the adoption of low-carbon agricultural systems in Mato Grosso, Brazil? Results from bioeconomic microsimulation. Regional Environmental Change 1-12. http://dx.doi.org/10.1007/s10113-017-1104-x

Chapin III, F. S., E. S. Zavaleta, V. T. Eviner, R. L. Naylor, P. M. Vitousek, H. L. Reynolds, D. U. Hooper, S. Lavorel, O. E. Sala, S. E. Hobbie, M. C. Mack, and S. Díaz. 2000. Consequences of changing biodiversity. Nature 405(6783):234-242. http://dx.doi. org/10.1038/35012241

Chaplin-Kramer, R., R. P. Sharp, L. Mandle, S. Sim, J. Johnson, I. Butnar, L. M. Canals, B. A. Eichelberger, I. Ramler, C. Mueller, N. McLachlan, A. Yousefi, H. King, and P. M. Kareiva. 2015. Spatial patterns of agricultural expansion determine impacts on biodiversity and carbon storage. Proceedings of the National Academy of Sciences 112(24):7402-7407. http://dx.doi.org/10.1073/ pnas. 1406485112
Cohn, A. S., A. Mosnier, P. Havlík, H. Valin, M. Herrero, E. Schmid, M. O'Hare, and M. Obersteiner. 2014. Cattle ranching intensification in Brazil can reduce global greenhouse gas emissions by sparing land from deforestation. Proceedings of the National Academy of Sciences 111(20):7236-7241. http://dx.doi. org/10.1073/pnas.1307163111

Coy, M. 2001a. Globalisierung in Brasilien: Raumwirksamkeit und Reaktionen. Beispiele aus städtischen und ländlichen Regionen. Pages 19-33 in A. Borsdorf, G. Krömer, and C. Parnreiter, editors. Lateinamerika im Umbruch. Geistige Strömungen im Globalisierungsstress. Innsbrucker Geographische Studien, Volume 32. Selbstverlag des Instituts für Geographie der Universität Innsbruck, Innsbruck, Austria.

Coy, M. 2001b. Institutionelle Regelungen im Konflikt um Land. Zum Stand der Diskussion. Geographica Helvetica 56(1):28-33. http://dx.doi.org/10.5194/gh-56-28-2001

Dalla-Nora, E. L., A. P. D. de Aguiar, D. M. Lapola, and G. Woltjer. 2014. Why have land use change models for the Amazon failed to capture the amount of deforestation over the last decade? Land Use Policy 39:403-411. http://dx.doi.org/10.1016/j. landusepol.2014.02.004

de Espindola, G. M., A. P. D. de Aguiar, E. Pebesma, G. Câmara, and L. Fonseca. 2012. Agricultural land use dynamics in the Brazilian Amazon based on remote sensing and census data. Applied Geography 32(2):240-252. http://dx.doi.org/10.1016/j. apgeog.2011.04.003

FAOSTAT. Food supply - crops primary equivalent. 2017. Food and Agriculture Organization of the United Nations, Rome, Italy. [online] URL: http://www.fao.org/faostat/en/\#data/CC

Fearnside, P. 2007. Brazil's Cuiabá-Santarém (BR-163) highway: the environmental cost of paving a soybean corridor through the Amazon. Environmental Management 39(5):601-614. http://dx. doi.org/10.1007/s00267-006-0149-2

Fearnside, P. M., C. A. Righi, P. M. Lima de Alencastro Graça, E. W. H. Keizer, C. C. Cerri, E. M. Nogueira, and R. I. Barbosa. 2009. Biomass and greenhouse-gas emissions from land-use change in Brazil's Amazonian "arc of deforestation": the states of Mato Grosso and Rondônia. Forest Ecology and Management 258(9):1968-1978. http://dx.doi.org/10.1016/j.foreco.2009.07.042

Fearnside, P. M. 2013. What is at stake for Brazilian Amazonia in the climate negotiations. Climatic Change 118(3):509-519. http://dx.doi.org/10.1007/s10584-012-0660-9

Fearnside, P. M. 2015. Deforestation soars in the Amazon. Nature 521:423.

Fearnside, P. M., A. M. Yanai, and C. S. M. N. Vitel. 2013. Modeling baselines for REDD projects in Amazonia: Is the carbon real? Pages 1-11 in Impacts of carbon-optimised land use management in southern Amazonia: multidisciplinary perspectives. Carbiocial, Universidade Federal de Mato Grosso (UFMT) \& FONA Research for Sustainable Development BMBF, Cuiabá, Mato Grosso, Brazil.

Folhes, R. T., A. P. D. de Aguiar, E. Stoll, E. L. Dalla-Nora, R. Araújo, A. Coelho, and O. do Canto. 2015. Multi-scale participatory scenario methods and territorial planning in the 
Brazilian Amazon. Futures 73:86-99. http://dx.doi.org/10.1016/j. futures.2015.08.005

Foweraker, J. 1981. The struggle for land: a political economy of the pioneer frontier in Brazil from 1930 to the present day. Cambridge University Press, Cambridge, UK. http://dx.doi. org/10.1017/cbo 9780511572258

Friedl, M. A., D. Sulla-Menashe, B. Tan, A. Schneider, N. Ramankutty, A. Sibley, and X. Huang. 2010. MODIS Collection 5 global land cover: algorithm refinements and characterization of new datasets. Remote Sensing of Environment 114(1):168-182. http://dx.doi.org/10.1016/j.rse.2009.08.016

Gerold, G., H. F. Jungkunst, K. M. Wanzen, R. Schönenberg, R. S. S. Amorim, E. G. Couto, B. Madari, and S. Hohnwald. 2014. Interdisciplinary analysis and modeling of carbon-optimized land management strategies for southern Amazonia. Universitätsdrucke Göttingen, Göttingen, Germany. http://dx.doi.org/10.17875/ gup2014-741

Gibbs, H. K., L. Rausch, J. Munger, I. Schelly, D. C. Morton, P. Noojipady, B. Soares-Filho, P. Barreto, L. Micol, and N. F. Walker. 2015. Brazil's soy moratorium. Science 347 (6220):377-378. http://dx.doi.org/10.1126/science.aaa0181

Gil, J., M. Siebold, and T. Berger. 2015. Adoption and development of integrated crop-livestock-forestry systems in Mato Grosso, Brazil. Agriculture, Ecosystems \& Environment 199:394-406. http://dx.doi.org/10.1016/j.agee.2014.10.008

Goepel, J., J. Schüngel, R. Schaldach, K. H. E. Meurer, H. F. Jungkunst, U. Franko, J. Boy, R. Strey, S. Strey, G. Guggenberger, A. Hampf, and P. Parker. 2017. Future land-use and land-cover in southern Amazonia and resulting greenhouse gas emissions from agricultural soils. Regional Environmental Change in press.

Gollnow, F., J. Göpel, L. deBarros Viana Hissa, R. Schaldach, and T. Lakes. 2017. Scenarios of land-use change in a deforestation corridor in the Brazilian Amazon: combining two scales of analysis. Regional Environmental Change 1-17. http://dx. doi.org/10.1007/s10113-017-1129-1

Gollnow, F., and T. Lakes. 2014. Policy change, land use, and agriculture: the case of soy production and cattle ranching in Brazil, 2001-2012. Applied Geography 55:203-211. http://dx.doi. org/10.1016/j.apgeog.2014.09.003

Hall, A., and S. Branford. 2012. Development, dams and Dilma: the saga of Belo Monte. Critical Sociology 38(6).

Hayes, N., and R. Rajão. 2011. Competing institutional logics and sustainable development: the case of geographic information systems in Brazil's Amazon Region. Information Technology for Development 17(1):4-23. http://dx.doi.org/10.1080/02681102.2010.511701

International Panel for Climate Change (IPCC). 2000. IPCC Special Report: emissions scenarios. A Special Report of IPCC Working Group III. IPCC, Geneva, Switzerland.

Jahn, T., M. Bergmann, and F. Keil. 2012. Transdisciplinarity: between mainstreaming and marginalization. Ecological Economics 79:1-10. http://dx.doi.org/10.1016/j.ecolecon.2012.04.017

Kalimili, B. B. N., and N. J. Fantom. 2016. The little data book 2016. World development indicators. World Bank Group,
Washington, D.C., USA. [online] URL: http://documents. worldbank.org/curated/en/974391468197395373/The-little-databook-2016

Kohlhepp, G. 2002. Regionalentwicklung im Amazonasgebiet Brasiliens. Institut Martius-Staden: Jahrbuch 49(2001-2002):182-216.

Kok, K., I. Bärlund, M. Flörke, I. Holman, M. Gramberger, J. Sendzimir, B. Stuch, and K. Zellmer. 2015. European participatory scenario development: strengthening the link between stories and models. Climatic Change 128(3-4):187-200. http://dx.doi.org/10.1007/s10584-014-1143-y

Kok, K., R. Biggs, and M. Zurek. 2007. Methods for developing multiscale participatory scenarios: insights from southern Africa and Europe. Ecology and Society 13(1):8. http://dx.doi. org/10.5751/es-01971-120108

Lambin, E. F., H. J. Geist, and E. Lepers. 2003. Dynamics of landuse and land-cover change in tropical regions. Annual Review of Environment and Resources 28:205-241 http://dx.doi.org/10.1146/ annurev.energy.28.050302.105459

Lapola, D. M., L. A. Martinelli, C. A. Peres, J. P. H. B. Ometto, M. E. Ferreira, C. A. Nobre, A. P. D. Aguiar, M. C. Bustamante, M. F. Caroso, M. H. Costa, et al. 2014. Pervasive transition of the Brazilian land-use system. Nature Climate Change 4(1):27-35. http://dx.doi.org/10.1038/nclimate2056

Lapola, D. M., R. Schaldach, J. Alcamo, A. Bondeau, J. Koch, C. Kölking, and J. A. Priess. 2010. Indirect land-use changes can overcome carbon savings by biofuels in Brazil. Proceedings of the National Academy of Sciences 107(8):3388-3393. http://dx.doi. org/10.1073/pnas.0907318107

Lapola, D. M., R. Schaldach, J. Alcamo, A. Bondeau, S. Msangi, J. A. Priess, and B. S. Soares-Filho. 2011. Impacts of climate change and the end of deforestation on land use in the Brazilian Legal Amazon. Earth Interactions 15(16):1-29. http://dx.doi. org/10.1175/2010ei333.1

Laurance, W. F., A. K. M. Albernaz, G. Schroth, P. Fearnside, S. Bergen, E. M. Venticinque, and C. Da Costa. 2002. Predictors of deforestation in the Brazilian Amazon. Journal of Biogeography 29(5-6):737-748. http://dx.doi.org/10.1046/j.1365-2699.2002.00721. $\underline{\mathrm{X}}$

Macedo, M. N., R. S. DeFries, D. C. Morton, C. M. Stickler, G. L. Galford, and Y. E. Shimabukuro. 2012. Decoupling of deforestation and soy production in the southern Amazon during the late 2000s. Proceedings of the National Academy of Sciences 109(4):1341-1346. http://dx.doi.org/10.1073/pnas.1111374109

Ministério da Agricultura, Pecuária e Abastecimento (MAPA). 2012. Plano Setorial de Mitigação e de Adaptação às Mudanças Climáticas para a Consolidação de uma Economia de baixa Emissão de Carbono na Agricultura. Plano ABC (Agricultura de Baixa Emissão de Carbono). Coordenado por Casa Civil da Presidência da República, Ministério da Agricultura, Pecuária e Abastecimento (MAPA) e Ministério do Desenvolvimento Agrário (MDA), Brasília, Brasil. Versão final-13/01. ISBN 978-85-7991-062-0

Moreira, E., S. Costa, A. P. D. Aguiar, G. Câmara, and T. Carneiro. 2009. Dynamical coupling of multiscale land change 
models. Landscape Ecology 24(9):1183-1194. DOI: 10.1007/ s10980-009-9397-x http://dx.doi.org/10.1007/s10980-009-9397-x

Nepstad, D., D. McGrath, C. Stickler, A. Alencar, A. Azevedo, B. Swette, T. Bezerra, M. DiGiano, J. Shimada, R. S. de Motta, et al. 2014. Slowing Amazon deforestation through public policy and interventions in beef and soy supply chains. Science 344 (6188):1118-1123. http://dx.doi.org/10.1126/science.1248525

Osuna, V. R., J. Börner, and M. Cunha. 2014. Scoping adaptation needs for smallholders in the Brazilian Amazon: a municipal level case study. Change and Adaptation in Socioecological Systems 1:12-25. http://dx.doi.org/10.2478/cass-2014-0002

Preti, O. 1993. A Fronteira Agrícola No Estado Brasileiro: Um Processo de Expasão, Acumulação E Luta. Cadernos Do Núcleo de Estudos Rurais E Urbanos, Cadernos do Neru, ICHS-UFMT 1:73-91.

Rao, C. R., H. Toutenburg, A. Fieger, C. Heumann, T. Nittner, and S. Scheid. 1999. Linear models: least squares and alternatives. Springer Series in Statistics, New York, New York, USA.

Richards, P. D., R. T. Walker, and E. Y. Arima. 2014. Spatially complex land change: the indirect effect of Brazil's agricultural sector on land use in Amazonia. Global Environmental Change 29:1-9. http://dx.doi.org/10.1016/j.gloenvcha.2014.06.011

Rosegrant, M. W. 2012. International model for policy analysis of agricultural commodities and trade (IMPACT): model description. International Food Policy Research Institute, Washington, D.C., USA.

Rounsevell, M. D., and M. J. Metzger. 2010. Developing qualitative scenario story lines for environmental change assessment. Climate Change 1(4):606-619. http://dx.doi. org/10.1002/wcc.63

Santos, R. 1980. História Econômica da Amazônia. 1880-1920. Queiroz Editora, Sao Pãulo, Brazil.

Schaldach, R., J. Alcamo, J. Koch, C. Kölking, D. M. Lapola, J. Schüngel, and J. A. Priess. 2011. An integrated approach to modelling land-use change on continental and global scales. Environmental Modelling \& Software 26(8):1041-1051. http://dx. doi.org/10.1016/j.envsoft.2011.02.013

Scholz, R. 2012. Environmental literacy in science and society: from knowledge to decisions. Cambridge University Press, Cambridge, UK.

Schönenberg, R. 2002. Die Kriminalisierung gesellschaftlicher Transformation in Amazonien. Hessische Stiftung Friedens und Konfliktforschung, Frankfurt am Main, Germany.

Schönenberg, R. 2011. Viel Land - Viel Streit. Konflikte und Konfliktlösungsstrategien in Amazonien. SVH, Saarbrücken, Germany.

Schönenberg, R., K. Hartberger, C. Schumann, J. H. Benatti, and L. da Cunha Fischer. 2015. What comes after deforestation control? Learning from three attempts of land-use planning in southern Amazonia. GAIA 24(2):119-127. http://dx.doi. org/10.14512/gaia.24.2.10

Schumann, C., K. Hartberger, M. Klingler, and R. Schönenberg. 2015. Sempre pra frente. Editora Olhares, São Paulo, Brazil.
Soares-Filho, B., A. Alencar, D. Nepstad, G. Cerqueira, M. del Carmen Vera Diaz, S. Rivero, L. Solorzano, and E. Voll. 2004. Simulating the response of land-cover changes to road paving and governance along a major Amazon highway: the SantarémCuiabá corridor. Global Change Biology 10:745-764. http://dx. doi.org/10.1111/j.1529-8817.2003.00769.x

Soares-Filho, B. S., D. C. Nepstad, L. Curran, G. C. Cerqueira, R. A. Garcia, C. A. Ramos, E. Voll, A. McDonald, P. Lefebvre, P. Schlesinger, and D. McGrath. 2005. Cenários de desmatamento para a Amazônia. Estudos Avançados 19(54):137-152. http://dx. doi.org/10.1590/s0103-40142005000200008

Soares-Filho, B., R. Rajao, M. Macedo, A. Carneiro, W. Costa, M. Coe, H. Rodrigues, and A. Alencar. 2014. Cracking Brazil's forest code. Science 344(6182):363-364. http://dx.doi.org/10.1126/ science. 1246663

Srinivasan C. S., X. Irz, and B. Shankar. 2006. An assessment of the potential consumption impacts of WHO 783 dietary norms in OECD countries. Food Policy 31(1):53-77. http://dx.doi. org/10.1016/j.foodpol.2005.08.002

Stehfest, E., L. Bouwman, D. P. van Vuuren, M. G. J. den Elzen, B. Eickhout, and P. Kabat. 2009. Climate benefits of changing diet. Climatic Change 95(1-2):83-102. http://dx.doi.org/10.1007/ s10584-008-9534-6

Stoll-Kleemann, S., and T. O'Riordan. 2015. The sustainability challenges of our meat and dairy diets. Environment 57(3):34-48. http://dx.doi.org/10.1080/00139157.2015.1025644

Tollefson J. 2016. Political upheaval threatens Brazil's environmental protections: barrage of proposals would allow developers to sidestep environmental reviews. Nature 539:147148. http://dx.doi.org/10.1038/539147a

Turner, B. L., E. F. Lambin, and A. Reenberg. 2007. The emergence of land change science for global environmental change and sustainability. Proceedings of the National Academy of Sciences 104(52):20666-20671. http://dx.doi.org/10.1073/ pnas.0704119104

U.S. Department of Agriculture Economic Research Service (USDA ERS). 2015. USDA Agricultural Projections to 2024. P. Westcott and J. Hansen. USDA Agricultural Projections No. OCE-151. USDA, Washington, D.C., USA.

Verburg, P. H., O. Mertz, K.-H. Erb, H. Haberl, and W. Wu. 2013. Land system change and food security: towards multi-scale land system solutions. Current Opinion in Environmental Sustainability 5(5):494-502. http://dx.doi.org/10.1016/j.cosust.2013.07.003

Verburg, P. H., C. J. E. Schulp, N. Witte, and A. Veldkamp. 2006. Downscaling of land use change scenarios to assess the dynamics of European landscapes. Agriculture, Ecosystems and Environment 114(1):39-56. http://dx.doi.org/10.1016/j.agee.2005.11.024

Vervoort, J. M., A. Palazzo, D. Mason-D’Croz, P. J. Ericksen, P. K. Thornton, P. Kristjanson, W. Förch, M. Herrero, P. Havlik, C. Jost, and H. Rowlands. 2013. The future of food security, environments and livelihoods in Eastern Africa: four socioeconomic scenarios. CCAFS Working Paper No. 63. CGIAR Research Program on Climate Change, Agriculture and Food Security, Copenhagen, Denmark. 
Woo-Cumings, M. 1999. The developmental state. Cornell University Press, Cornell, New York, USA.

World Trade Organization (WTO). 2016. World trade statistical review 2016. Brookings Institution Press, Washington, D.C., USA. 
Appendix 1. Story line assumptions, scenario interpretation, and quantification of Carbiocial scenarios for MT/PA as well as BR-163 corridor.

Table A1.1. Translation of story line statements to model drivers (Trend Scenario).

\begin{tabular}{|c|c|c|}
\hline Storyline Assumption & Scenario Interpretation & Quantification \\
\hline \multicolumn{3}{|l|}{ Population } \\
\hline $\begin{array}{l}\text { population dynamics and } \\
\text { growth continue according } \\
\text { to agricultural pioneer } \\
\text { frontier dynamics }\end{array}$ & $\begin{array}{l}\text { population growth } \\
\text { according to past } \\
\text { observations }\end{array}$ & $\begin{array}{l}\text { trend projection (method of the least squares) } \\
\text { until } 2030\end{array}$ \\
\hline \multicolumn{3}{|l|}{ Agricultural Development } \\
\hline $\begin{array}{l}\text { agricultural production is } \\
\text { expanding and intensifying }\end{array}$ & $\begin{array}{l}\text { agricultural production } \\
\text { growth according to past } \\
\text { observations }\end{array}$ & $\begin{array}{l}\text { trend projection (method of the least squares) } \\
\text { until } 2030\end{array}$ \\
\hline $\begin{array}{l}\text { livestock numbers continue } \\
\text { to rise }\end{array}$ & $\begin{array}{l}\text { livestock number growth } \\
\text { according to past } \\
\text { observations }\end{array}$ & $\begin{array}{l}\text { trend projections (method of the least squares) } \\
\text { until } 2030\end{array}$ \\
\hline \multicolumn{3}{|l|}{ Land-use policy } \\
\hline $\begin{array}{l}\text { conversion of natural } \\
\text { ecosystems is taking place }\end{array}$ & $\begin{array}{l}\text { no further constraint } \\
\text { regarding conversion of } \\
\text { natural ecosystems }\end{array}$ & $\begin{array}{l}\text { transition probability forest: } 50 \% \text { (due to cost of } \\
\text { conversion) } \\
\text { transition probability Cerrado: } 70 \% \text { (due to cost } \\
\text { of conversion) }\end{array}$ \\
\hline $\begin{array}{l}\text { law enforcement in place } \\
\text { but rather inefficient due to } \\
\text { resource deficiency }\end{array}$ & $\begin{array}{l}\text { MT/PA: } \\
\text { no further land-use change } \\
\text { in protected areas (strictly } \\
\text { protected, sustainable use, } \\
\text { military, indigenous) } \\
\text { BR-163 corridor: } \\
\text { some land-use changes may } \\
\text { occur in strictly protected } \\
\text { areas and sustainable use } \\
\text { areas }\end{array}$ & $\begin{array}{l}\text { BR-163 corridor: } \\
\text { no land conversion within protected areas; every } \\
\text { second year: land conversion allowed within } \\
\text { areas of sustainable use; } \\
\text { every fourth year: land conversion allowed } \\
\text { within strictly protected areas }\end{array}$ \\
\hline $\begin{array}{l}\text { infrastructural development } \\
\text { continues as planned: BR- } \\
163 \text { paved }\end{array}$ & $\begin{array}{l}\text { BR-163 will be paved from } \\
\text { Cuiabá to Satarém }\end{array}$ & $\begin{array}{l}\text { BR-163 is integrated into database road-map } \\
\text { layer as paved road }\end{array}$ \\
\hline
\end{tabular}


Table A1.2. Translation of story line statements to model drivers (Legal Intensification Scenario).

\begin{tabular}{|c|c|c|}
\hline Story line Assumption & Scenario Interpretation & Quantification \\
\hline \multicolumn{3}{|l|}{ Population } \\
\hline $\begin{array}{l}\text { population dynamics and } \\
\text { growth continue according } \\
\text { to agricultural pioneer } \\
\text { frontier dynamics }\end{array}$ & $\begin{array}{l}\text { population growth according } \\
\text { to past observations }\end{array}$ & $\begin{array}{l}\text { trend projection (method of the least squares) } \\
\text { until } 2030\end{array}$ \\
\hline \multicolumn{3}{|l|}{ Agricultural Development } \\
\hline $\begin{array}{l}\text { agricultural production is } \\
\text { expanding and intensifying }\end{array}$ & $\begin{array}{l}\text { agricultural production is } \\
\text { expanding and intensifying } \\
\text { further accelerated due to } \\
\text { demand from Asian } \\
\text { countries }\end{array}$ & $\begin{array}{l}\text { trend projections (method of the least squares) } \\
\text { until } 2030+\text { additional growth according to } \\
\text { population growth in Asian countries }\end{array}$ \\
\hline $\begin{array}{l}\text { livestock numbers continue } \\
\text { to rise }\end{array}$ & $\begin{array}{l}\text { livestock numbers continue } \\
\text { to rise further accelerated } \\
\text { due to demand from Asian } \\
\text { countries }\end{array}$ & $\begin{array}{l}\text { trend projections (method of the least squares) } \\
\text { until } 2030+\text { additional growth according to } \\
\text { population growth in Asian countries }\end{array}$ \\
\hline $\begin{array}{l}\text { tendency toward } \\
\text { intensification of pasture } \\
\text { management }\end{array}$ & $\begin{array}{l}\text { increases of livestock } \\
\text { production are realized } \\
\text { through intensification } \\
\text { rather than expansion of } \\
\text { productive land to an } \\
\text { increasing extent }\end{array}$ & $\begin{array}{l}\text { net primary productivity of pasture cells is } \\
\text { successively increased until } 2030(\mathrm{MT}:+9 \% \\
\text { per time step, max: }+50 \% \text {; PA: }+4.5 \% \text { per time } \\
\text { step, max: }+30 \%)\end{array}$ \\
\hline \multicolumn{3}{|l|}{ Land-use policy } \\
\hline $\begin{array}{l}\text { conversion of natural } \\
\text { ecosystems is taking place }\end{array}$ & $\begin{array}{l}\text { no further constraint } \\
\text { regarding conversion of } \\
\text { natural ecosystems }\end{array}$ & $\begin{array}{l}\text { transition probability forest: } 50 \% \text { (due to cost } \\
\text { of conversion) } \\
\text { transition probability Cerrado: } 70 \% \text { (due to } \\
\text { cost of conversion) }\end{array}$ \\
\hline effective law enforcement & $\begin{array}{l}\text { no further land-use change } \\
\text { in protected areas (strictly } \\
\text { protected, sustainable use, } \\
\text { military, indigenous) }\end{array}$ & $\begin{array}{l}\text { MT/PA: } \\
\text { land-use type within protected areas is not } \\
\text { changed } \\
\text { BR-163 corridor: } \\
\text { and-use according to TerraClass land cover } \\
\text { classification }\end{array}$ \\
\hline 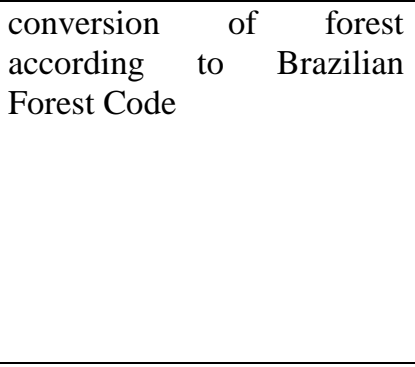 & $\begin{array}{l}\text { of every converted forest } \\
\text { cell, a portion of } 80 \% \\
\text { remains unchanged while } \\
20 \% \text { are converted into } \\
\text { agricultural land }\end{array}$ & $\begin{array}{l}\text { MT/PA: } \\
\text { all newly established agricultural land-use on } \\
\text { former forest cells as mosaic land-use type } \\
\text { (Mosaic "Legal Reserve") } 20 \% \text { cropland or } \\
\text { pasture/80\% rainforests } \\
\text { BR-163 corridor: } \\
\text { 80\% of available forest cover per municipality } \\
\text { remains forest throughout simulation }\end{array}$ \\
\hline $\begin{array}{l}\text { infrastructural development } \\
\text { continues as planned: BR- } \\
163 \text { paved }\end{array}$ & $\begin{array}{l}\text { BR-163 will be paved from } \\
\text { Cuiabá to Satarém }\end{array}$ & $\begin{array}{l}\text { BR-163 is integrated into database road-map } \\
\text { layer as paved road }\end{array}$ \\
\hline
\end{tabular}


Table A1.3. Translation of story line statements to model drivers (Illegal Intensification Scenario).

\begin{tabular}{|c|c|c|}
\hline Story line Assumption & Scenario Interpretation & Quantification \\
\hline \multicolumn{3}{|l|}{ Population } \\
\hline $\begin{array}{l}\text { population dynamics and } \\
\text { growth continue according } \\
\text { to agricultural pioneer } \\
\text { frontier dynamics }\end{array}$ & $\begin{array}{l}\text { population growth according } \\
\text { to past observations }\end{array}$ & $\begin{array}{l}\text { trend projection (method of the least squares) } \\
\text { until } 2030\end{array}$ \\
\hline \multicolumn{3}{|l|}{ Agricultural Development } \\
\hline $\begin{array}{l}\text { agricultural production is } \\
\text { expanding and intensifying }\end{array}$ & $\begin{array}{l}\text { agricultural production is } \\
\text { expanding and intensifying } \\
\text { further accelerated due to } \\
\text { demand from Asian } \\
\text { countries }\end{array}$ & $\begin{array}{l}\text { trend projections (method of the least squares) } \\
\text { until } 2030+\text { additional growth according to } \\
\text { population growth in Asian countries }\end{array}$ \\
\hline $\begin{array}{l}\text { livestock numbers continue } \\
\text { to rise }\end{array}$ & $\begin{array}{l}\text { livestock numbers continue } \\
\text { to rise further accelerated } \\
\text { due to demand from Asian } \\
\text { countries }\end{array}$ & $\begin{array}{l}\text { trend projections (method of the least squares) } \\
\text { until } 2030+\text { additional growth according to } \\
\text { population growth in Asian countries }\end{array}$ \\
\hline $\begin{array}{l}\text { tendency toward } \\
\text { intensification of pasture } \\
\text { management }\end{array}$ & $\begin{array}{l}\text { increases of livestock } \\
\text { production are realized } \\
\text { through intensification } \\
\text { rather than expansion of } \\
\text { productive land to an } \\
\text { increasing extent }\end{array}$ & $\begin{array}{l}\text { net primary productivity of pasture cells is } \\
\text { successively increased until } 2030(\mathrm{MT}:+9 \% \\
\text { per time step, max: }+50 \% \text {; PA: }+4.5 \% \text { per time } \\
\text { step, max: }+30 \%)\end{array}$ \\
\hline \multicolumn{3}{|l|}{ Land-use policy } \\
\hline $\begin{array}{l}\text { conversion of natural } \\
\text { ecosystems is taking place }\end{array}$ & $\begin{array}{l}\text { no further constraint } \\
\text { regarding conversion of } \\
\text { natural ecosystems }\end{array}$ & $\begin{array}{l}\text { transition probability forest: } 50 \% \text { (due to cost } \\
\text { of conversion) } \\
\text { transition probability Cerrado: } 70 \% \text { (due to } \\
\text { cost of conversion) }\end{array}$ \\
\hline $\begin{array}{l}\text { ecological protected areas } \\
\text { are used for illegal } \\
\text { agricultural expansion; } \\
\text { sporadic law enforcement }\end{array}$ & $\begin{array}{l}\text { MT/PA: } \\
\text { no land use within protected } \\
\text { areas (military, indigenous); } \\
\text { land use/land use change } \\
\text { allowed in ecological } \\
\text { protected areas } \\
\text { BR-163 corridor: } \\
\text { road between BR-163 and } \\
\text { Terra do Meio protected } \\
\text { areas are used for illegal } \\
\text { agricultural expansion }\end{array}$ & $\begin{array}{l}\text { BR-163 corridor: } \\
\text { road construction between Novo Progresso and } \\
\text { Felix do Xingu; military/indigenous areas } \\
\text { considered protected; sustainable use, strictly } \\
\text { protected and riparian protected areas not } \\
\text { protected }\end{array}$ \\
\hline $\begin{array}{l}\text { infrastructural development } \\
\text { continues as planned: BR- } \\
163 \text { paved }\end{array}$ & $\begin{array}{l}\text { BR-163 will be paved from } \\
\text { Cuiabá to Satarém }\end{array}$ & $\begin{array}{l}\text { BR-163 is integrated into database road-map } \\
\text { layer as paved road }\end{array}$ \\
\hline
\end{tabular}


Table A1.4. Translation of story line statements to model drivers (Sustainable Development Scenario).

\begin{tabular}{|c|c|c|}
\hline Story line Assumption & Scenario Interpretation & Quantification \\
\hline \multicolumn{3}{|l|}{ Population } \\
\hline $\begin{array}{l}\text { population } r \text { growth } \\
\text { stabilizing; less migration } \\
\text { of land-less from other } \\
\text { Brazilian regions }\end{array}$ & $\begin{array}{lll}\text { population growth rate } \\
\text { decreasing }\end{array}$ & $\begin{array}{l}\text { trend projections (method of the least squares) } \\
\text { until } 2030 \text { - growth rate correction (MT: }-10 \% \text {; } \\
\text { PA: }-5 \% \text { ) per time-step }\end{array}$ \\
\hline \multicolumn{3}{|l|}{ Agricultural Development } \\
\hline $\begin{array}{l}\text { agricultural production } \\
\text { specializing on fresh } \\
\text { products (niche market); the } \\
\text { better the development of } \\
\text { trade structures, the stronger } \\
\text { smallholder and medium } \\
\text { business production }\end{array}$ & $\begin{array}{l}\text { agricultural production } \\
\text { focusing on production of } \\
\text { vegetarian products; focus } \\
\text { on crops for domestic use; } \\
\text { focus away from cash crops }\end{array}$ & $\begin{array}{l}\text { trend projections (method of the least squares) } \\
\text { until } 2030 \text { + additional production growth } \\
\text { (pulses, fruits, vegetables, soy); production } \\
\text { correction of soybean (exported fraction) due } \\
\text { to less export demand }\end{array}$ \\
\hline $\begin{array}{l}\text { worldwide trend toward } \\
\text { vegetarian diet }\end{array}$ & $\begin{array}{l}\text { livestock numbers decrease } \\
\text { considerably; meat } \\
\text { consumption substituted by } \\
\text { vegetarian products }\end{array}$ & $\begin{array}{l}\text { trend projections (method of the least squares) } \\
\text { until } 2030-70 \% \text { of total livestock numbers due } \\
\text { to healthy and sustainable diet }\end{array}$ \\
\hline $\begin{array}{l}\text { high intensification } \\
\text { regarding agricultural } \\
\text { practices }\end{array}$ & $\begin{array}{l}\text { crop yield data increases } \\
\text { further }\end{array}$ & $\begin{array}{l}\text { crop yield growth adapted by an additional } \\
+30 \% \text { of crop biomass over } 30 \text { years }\end{array}$ \\
\hline \multicolumn{3}{|l|}{ Land-use policy } \\
\hline $\begin{array}{l}\text { effective law enforcement; } \\
\text { Soy Moratorium continues } \\
\text { after 2016; Cattle } \\
\text { Moratorium continues after } \\
2019\end{array}$ & $\begin{array}{l}\text { MT/PA: } \\
\text { conversion of areas defined } \\
\text { as Cerrado less likely to } \\
\text { happen; conversion of forest } \\
\text { areas not possible; } \\
\text { BR-163 corridor: } \\
\text { Soy Moratorium prohibits } \\
\text { the conversion of deforested } \\
\text { lands to cropland after } 2006 \text {; } \\
\text { Cattle Moratorium prohibits } \\
\text { conversion of deforested } \\
\text { land to pasture after } 2009\end{array}$ & $\begin{array}{l}\text { MT/PA: } \\
\text { transition probability forest: } 0 \% \text {; transition } \\
\text { probability Cerrado: } 30 \% \text {; } \\
\text { BR-163 corridor: } \\
\text { no conversion to cropland on areas deforested } \\
\text { after } 2006 \text {; no conversion to pasture on areas } \\
\text { deforested after } 2009\end{array}$ \\
\hline $\begin{array}{l}\text { protected areas continue to } \\
\text { play an important role in } \\
\text { conservation of natural } \\
\text { ecosystems }\end{array}$ & $\begin{array}{l}\text { MT/PA: } \\
\text { no further land-use change } \\
\text { in protected areas (strictly } \\
\text { protected, sustainable use, } \\
\text { military, indigenous) }\end{array}$ & $\begin{array}{l}\text { MT/PA: } \\
\text { land-use type within all protected areas is not } \\
\text { changed }\end{array}$ \\
\hline $\begin{array}{l}\text { infrastructural development } \\
\text { continues as planned: BR- } \\
163 \text { paved }\end{array}$ & $\begin{array}{l}\text { BR-163 will be paved from } \\
\text { Cuiabá to Satarém }\end{array}$ & $\begin{array}{l}\text { BR-163 is integrated into database road-map } \\
\text { layer as paved road }\end{array}$ \\
\hline
\end{tabular}


Table A1.5. Population development in Pará and Mato Grosso; population numbers in 2010 and change rates until 2030.

\begin{tabular}{|l|l|l|l|l|}
\hline \multirow{2}{*}{ State } & 2010 & \multicolumn{3}{|c|}{ Change 2010 - 2030 [\%] } \\
\cline { 2 - 5 } & Population & Trend & $\begin{array}{l}\text { Legal/Illegal } \\
\text { Intensification }\end{array}$ & $\begin{array}{l}\text { Sustainable } \\
\text { Development }\end{array}$ \\
\hline Pará & $6,913,180$ & +35 & +35 & +32 \\
\hline Mato Grosso & $2,795,890$ & +35 & +35 & +29 \\
\hline
\end{tabular}

Table A1.6. Agricultural development.

\begin{tabular}{|c|c|c|c|c|c|c|c|c|c|}
\hline & \multirow[t]{3}{*}{ Crop type } & \multicolumn{4}{|c|}{ Crop yield } & \multicolumn{4}{|c|}{ Crop production } \\
\hline & & \multirow{2}{*}{$\begin{array}{l}\text { [t/ha] } \\
2010\end{array}$} & \multicolumn{3}{|c|}{ Change $2010-2030[\%]$} & \multirow{2}{*}{$\begin{array}{l}{[\mathrm{kt}]} \\
2010\end{array}$} & \multicolumn{3}{|c|}{ Change $2010-2030[\%]^{1}$} \\
\hline & & & Trend & $\begin{array}{l}\text { Legal/Illegal } \\
\text { Intensification }\end{array}$ & $\begin{array}{l}\text { Sustainable } \\
\text { development }\end{array}$ & & Trend & $\begin{array}{l}\text { Legal/Illegal } \\
\text { Intensification }\end{array}$ & $\begin{array}{l}\text { Sustainable } \\
\text { development }\end{array}$ \\
\hline \multirow{8}{*}{ 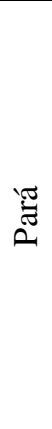 } & Fruits & 16.05 & +42.35 & +42.35 & +85.06 & 740.67 & +123.52 & +123.52 & +273.58 \\
\hline & Maize & 3.81 & +70.32 & +70.32 & +121.42 & 519.25 & +89.36 & +129.13 & +55.59 \\
\hline & Groundnut & 2.1 & +40.37 & +40.37 & +82.48 & 0.19 & +109.73 & +109.73 & +57.93 \\
\hline & Beans & 0.76 & +49.41 & +49.41 & +94.23 & 36.49 & +146.83 & +146.83 & +1978.76 \\
\hline & Rice & 2.64 & +61.56 & +61.56 & +110.03 & 263.87 & +145.35 & +145.35 & +125.74 \\
\hline & Cassava & 16.49 & +45.92 & +45.92 & +89.70 & 4596 & +67.11 & +67.11 & +88.82 \\
\hline & Soybean & 2.86 & +39.16 & +39.16 & +80.91 & 243.61 & +177.75 & +236.07 & +2447.96 \\
\hline & Sugarcane & 81.31 & +51.40 & +51.40 & +96.82 & 668.74 & +8.12 & +8.12 & +8.12 \\
\hline \multirow{8}{*}{ 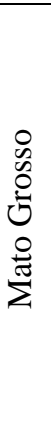 } & Fruits & 16.05 & +42.35 & +42.35 & +85.06 & 57.77 & +226.64 & +226.64 & +542.83 \\
\hline & Maize & 3.81 & +70.32 & +70.32 & +121.42 & 8164 & -0.53 & +20.36 & +69.15 \\
\hline & Groundnut & 2.1 & +40.37 & +40.37 & +82.48 & 4.52 & -13.19 & -13.19 & +55.02 \\
\hline & Beans & 0.76 & +49.41 & +49.41 & +94.23 & 133.81 & -24.39 & -24.39 & +701.28 \\
\hline & Rice & 2.64 & +61.56 & +61.56 & +110.03 & 686.3 & +97.44 & +97.44 & +125.74 \\
\hline & Cassava & 16.49 & +45.92 & +45.92 & +89.70 & 496 & +8.79 & +8.79 & +103.03 \\
\hline & Soybean & 2.86 & +39.16 & +39.16 & +80.91 & 4921 & +42.05 & +71.88 & +119.70 \\
\hline & Sugarcane & 81.31 & +51.40 & +51.40 & +96.82 & 9390 & +71.88 & +71.88 & +71.88 \\
\hline
\end{tabular}

\footnotetext{
${ }^{1}$ high change rates (beans, soy) due to substitution of dietary meat intake and relatively low production values in 2010
} 